LESZEK ZYGNER ${ }^{1}$

Państwowa Uczelnia Zawodowa

im. Ignacego Mościckiego w Ciechanowie

\title{
ŻYCIE SYNODALNE METROPOLII GNIEŹNIEŃSKIEJ ORAZ DIECEZJI PRUSKICH I FRANKOŃSKICH KOŃCA XIV I PIERWSZEJ POLOWY XV WIEKU (UWAGI NA MARGINESIE NAJNOWSZYCH BADAŃ) - CZ. 1
}

\section{Synodal life of the Gniezno metropolis and the Prussian and Franconian dioceses at the end of the 14th and first half of the 15th centuries (comments on the margins of the latest studies) - part 1}

\section{Abstract}

The subject of this paper are the synods of the Gniezno metropolis as well as the Prussian and Franconian dioceses of 1378-1449. According to the preserved sources, 71 diocesan synods took place during that period, including 43 in the metropolis of Gniezno, 15 in the Prussian dioceses, and 13 in the Franconian dioceses as well as 17 provincial synods (14 in the metropolis of and 3 in the metropolis of Riga). The frequency of synods in individual dioceses confirms that after the period of stagnation that began in the mid-fourteenth century, there was a significant synodal revival in the first half of the fifteenth century, especially during the Council of Basel, and then of Florence and Rome.

Keywords: synodal life, Poland, Prussia, Franconia, late Middle Ages

\begin{abstract}
Abstrakt
Przedmiotem niniejszego artykułu są synody metropolii gnieźnieńskiej oraz diecezji pruskich i frankońskich z lat 1378-1449. Z zachowanych źródeł wynika, że w okresie tym odbyło się 71 synodów diecezjalnych, z czego w metropolii gnieźnieńskiej - 43, w diecezjach pruskich - 15 i w diecezjach frankońskich - 13, a także zwołano 17 synodów prowincjonalnych (w metropolii gnieźnieńskiej - 14 i w metropolii ryskiej - 3). Częstotliwość synodów w poszczególnych diecezjach potwierdza, że po okresie pewnego zastoju, który występował

\footnotetext{
1 Niniejszy tekst powstał w ramach projektu badawczego KAAD (Katholischer Akademischer Ausländer-Dienst) pt. „Synodale Aktivität in polnischen und deutschen Diözesen um die Wende des 14. und 15. Jahrhunderts” (2019) realizowanego na Julius-Maximilians-Universität w Würzburgu oraz Georg-August-Universität w Getyndze.

Leszek Zygner, profesor i rektor Państwowej Uczelni Zawodowej im. Ignacego Mościckiego w Ciechanowie. Specjalizuje się w historii Kościoła epoki średniowiecza i czasów najnowszych, a także w badaniach nad dziejami Mazowsza. E-mail: leszekzygner@gmail.com.
} 
od połowy XIV wieku, nastąpiło znaczne ożywienie synodalne w pierwszej połowie XV wieku, a zwłaszcza w okresie trwania soboru w Bazylei, a potem we Florencji i w Rzymie.

Słowa kluczowe: życie synodalne, Polska, Prusy, Frankonia, późne średniowiecze

$\dot{\mathrm{Z}}$ ycie synodalne Kościołów partykularnych okresu późnego średniowiecza realizowane W oparciu o instytucję synodów prowincjonalnych i diecezjalnych stanowi przedmiot badań historyków już od blisko dwóch wieków. W badaniach tych ważne miejsce zajmuje historia porównawcza synodów podejmowana w ramach projektów badawczych, a także będąca tematem konferencji i publikacji naukowych. Przykładem może być między innymi zgłoszony w 2001 r. projekt badawczy Johannesa Helmratha w odniesieniu do synodów partykularnych średniowiecznej Europy ${ }^{2}$ czy realizowany obecnie na uniwersytecie w Passau pod kierunkiem Thomasa Wünscha projekt dotyczący synodów prowincjonalnych polskich i czeskich w średniowieczu ${ }^{3}$, a także wydany w 2006 r. tom studium „Partikularsynoden im späten Mittelalter”, będący pokłosiem międzynarodowej konferencji naukowej z udziałem historyków niemieckich, polskich i czeskich na temat synodów w Europie Środkowo-Wschodniej zorganizowanej przez działający w strukturach dawnego Max-Planck-Institut für Geschichte w Getyndze projekt „Germania Sacra” oraz Polską Misję Historyczną ${ }^{4}$ Do nurtu badań historii porównawczej średniowiecznych synodów nawiązuje również niniejszy tekst, a jego głównym celem jest próba podsumowania najważniejszych badań ostatniego ćwierćwiecza odnoszących się do życia synodalnego w gnieźnieńskiej prowincji kościelnej (arcybiskupstwo w Gnieźnie oraz biskupstwa w Krakowie, Lubuszu, Miednikach, Płocku, Poznaniu, Wilnie, Włocławku i Wrocławiu) oraz w czterech diecezjach pruskich (chełmińskiej, pomezańskiej, sambijskiej i warmińskiej) i w trzech diecezjach frankońskich (Bamberg, Eichstätt, Würzburg) w okresie od wybuchu wielkiej schizmy zachodniej (1378) do zakończenia schizmy bazylejskiej (1449). Wybrany okres nie jest przypadkowy, gdyż nawiązuje do podkreślanego przez historyków zjawiska w dziejach synodów polegającego na tym, że po ok. 1330/1350 r. w wielu prowincjach kościelnych zmalała aktywność synodalna, po czym jej powtórne ożywienie nastąpiło w pierwszej połowie XV wieku, co zdaniem badaczy miało związek z ówczesną odnową Kościoła podjętą na soborach reformistycznych ${ }^{5}$, która poza przywróceniem jedności w Kościele i reformą papiestwa, stawiała sobie za cel również odnowę Kościołów lokalnych i tym samym oddziaływała na ustawodawstwo

\footnotetext{
J. Helmrath, Partikularsynoden und Synodalstatuten des späteren Mittelalters im europäischen Vergleich. Vorüberlegungen zu einem möglichen Projekt, w: Das europäische Mittelalter im Spannungsbogen des Vergleichs. Zwanzig internationale Beiträge zu Praxis, Problemen und Perspektiven der historischen Komparatistik, red. M. Borgolte, Berlin 2001, s. 135-169.

3 Mam tu na myśli projekt „Konzilienlexikon Polen und Böhmen” (phil.uni-passau.de/neuere-geschichte-osteuropas/forschung/projekt-konzilienlexikon/), realizowany w ramach szerszego (międzynarodowego) projektu badawczego „Lexikon der Konzilien”, kierowanego przez Mansi-Institut w Bambergu, pod patronatem kard. Waltera Brandmüllera (uni-bamberg.de/?id=29720). Zob. także Th. Wünsch, Typologie und Funktionalität der polnischen Synoden. Neue Fragenstellungen, „Annuarium Historiae Conciliorum”, 40/2008, s. 561-570; idem, Ritual und Politik. Partikularsynoden als Instrumente der politischen Willensbildung in der polnisch-litauischen Adelsrepublik, w: Ritualisierung politischer Willensbildung. Polen und Deutschland im hohen und späten Mittelalter, red. W. Fałkowski, B. Schneidmüller, S. Weinfurter, Wiesbaden 2010, s. 243-258.

4 Partikularsynoden im späten Mittelalter, red. N. Kruppa, L. Zygner, Göttingen 2006.

5 J. Helmrath, Partikularsynoden, op. cit., s. 149. Zob. także H.-J. Schmidt, Kirche, Staat, Nation. Raumgliederung der Kirche im mittelalterlichen Europa, Weimar 1999, s. 158-160.
} 
synodów partykularnych pierwszej połowy XV wieku'. Trzymając się więc zakreślonych ram chronologicznych, chciałbym w niniejszym szkicu podsumować obecny stan badań w odniesieniu do synodów oraz ustawodawstwa synodalnego wymienionych w tytule diecezji, a także zgłosić, ewentualnie przypomnieć za innymi historykami, postulaty, które powinny być w przyszłości uwzględnione przez badaczy zajmujących się problematyką synodalną.

\section{Stan badań}

Zainicjowane w XIX wieku badania nad synodami i ustawodawstwem synodalnym Europy Zachodniej zaowocowały edycjami statutów synodalnych diecezji niemieckich ${ }^{7}$, w tym również diecezji frankońskich i pruskich ${ }^{8}$. Na wzór historyków zachodnich podobne badania podjęli również polscy historycy, a ich efektem były między innymi edycje statutów i studia nad synodami w ramach serii wydawniczych „Starodawne prawa polskiego pomniki”, „Studia i materiały do historii ustawodawstwa synodalnego w Polsce” i „Concilia Poloniae.

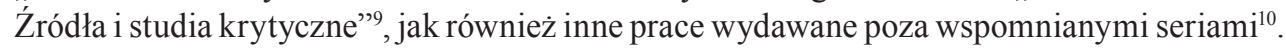

6 Więcej na ten temat: L. Zygner, Późnośredniowieczne synody narzędziem reformy Kościoła, w: Ecclesia semper reformanda. Kryzysy i reformy średniowiecznego Kościoła, red. T. Gałuszka, T. Graff, G. Ryś, Kraków 2013, s. 423-441.

7 Jedna z najważniejszych prac, którą wówczas powstała to dzieło Antona Josepha Binterima, Pragmatische Geschichte des deutschen National-, Provinzial- und vorzüglichsten Diöcesanconcilien vom vierten Jahrhundert bis auf das Concilium zu Trient, t. 1-7, Mainz 1835-1848.

8 H.F. Jacobson, Geschichte der Quellen der katholischen Kirchenrechts der Provinzen Preussen und Posen mit Urkunden und Regesten, Königsberg 1837; Die Bamberger Synoden, ed. L.C. Schmitt, Bamberg 1851; J.G. Suttner, Versuch einer Conciliengeschichte des Bisthums Eichstätt, „Pastoralblatt des Bisthums Eichstätt”, 1/1854, s. 15-16, 19-20, 26-28, 31-32, 36, 38-40, 42-44, 46-48, 50-52, 54-60, 62-64, 66-68, 74-76, 78-80, 85-88, 90-100, 102-104, $108,110-112,114-116,118-124,128,131-32,135-136,138-140,147-148,150-152,158-160,163-164,167-172$, 174-188, 191-192, 194-195, 198-200, 202-204, 206-208, 211-224; idem, Nachträge zur Conciliengeschichte des Bisthums Eichstätt, „Pastoralblatt des Bisthums Eichstätt”, 4/1857, s. 193-198; Synodicon Herbipolense. Geschichte und Statuten der im Bisthum Würzburg gehaltenen Concilien und Dioecesansynoden, ed. F.X. Himmelstein, Würzburg 1855; Constitutiones synodales Warmienses, Sambienses, Pomesanienses, Culmenses necnon provinciales Rigenses, ed. F. Hipler, Brunsberga 1899; O. Günther, Eine Predigt vom preußischen Provinzialkonzil in Elbing 1427 und die „Ermahnung des Carthäusers”, „Zeitschrift des Westpreussischen Geschichtsvereins”, 59/1919, s. 69-111; C. Krollmann, Eine merkwürdige samländische Urkunde, „Altpreußische Forschungen”, 11/1934, s. 32-38 (tu statuty synodalne sambijskie z początku XIV wieku); E.O. Kehrberger, Provinzial- und Synodalstatuten des Spätmittelalters. Eine quellenkritische Untersuchung der Mainzer Provinzialgesetze des 14. und 15. Jahrhunderts und der Synodalstatuten der Diözesen Bamberg, Eichstätt und Konstanz, Stuttgart 1938.

$9 \quad$ Na temat polskich badań nad synodami pisali: J. Sawicki, Geschichte und heutiger Stand der Vorarbeiten zur Gesamtausgabe der polnischen Synodalstatuten, „Zeitschrift der Savigny-Stiftung für Rechtsgeschichte. Kanonistische Abteilung”, 46/1960, s. 395-429; W. Góralski, Stan badań nad średniowiecznym polskim ustawodawstwem synodalnym, „Studia Warmińskie”, 27/1990, s. 13-36. J. Dudziak, Der gegenwärtige Stand der kirchlichen Rechtsgeschichte in Polen. Ein Grundriß, ,Zeitschrift der Savigny-Stiftung für Rechtsgeschichte. Kanonistische Abteilung”, 81/1995, s. 318-327; L. Zygner, ,, Concilia Poloniae”-niedokończona seria wydawnicza, w: Editiones sine fine, t. 1, red. K. Kopiński, W. Mrozowicz, J. Tandecki, Toruń 2017, s. 189-201.

10 Zob. np. Antiquissimae constitutiones synodales provinciae Gnesnensis, ed. R. Hube, Petersburg 1856; P.W. Fabisz, Wiadomość o synodach prowincyalnych gnieźnieńskich i o prawach kościoła polskiego z dodatkiem spisu synodów dyecezjalnych polskich, Kępno 1861; T. Gromnicki, Synody prowincjonalne oraz czynności niektórych funkcjonariuszów apostolskich w Polsce do r. 1457, Kraków 1885; B. Ulanowski, O pracach przygotowawczych do historii prawa kanonicznego w Polsce, Kraków 1887, s. 31-42 (statuty synodu krakowskiego z lat 1392-1396 ); Statuta synodalia dioecesi Wladislaviensis et Pomeraniae, ed. Z. Chodyński, Varsaviae 1890; S. Zachorowski, Studia z historii prawa kościelnego i polskiego, Kraków 1917, s. 81-148 (synody diecezjalne z lat 1423-1427); Constitutiones synodales necnon ordinationes dioecesis Culmensis, Pars I, ed. A. Mańkowski, Torunii 1929; M. Morawski, Synod prowincjonalny prowincji gnieźnieńskiej w dawnej Polsce, Włocławek 1935; idem, Synod diecezjalny w dawnej Polsce, Włocławek 1937. 
Jednak ożywienie w badaniach nad średniowiecznymi synodami diecezji pruskich oraz synodów frankońskich widoczne zwłaszcza w XIX wieku, a w odniesieniu do metropolii gnieźnieńskiej także w pierwszej połowie XX wieku, znacznie osłabło w drugiej połowie minionego stulecia i dopiero na przełomie XX i XXI wieku problematyka ta na nowo spotkała się z większym zainteresowaniem historyków ${ }^{11}$. W okresie ostatniego ćwierćwiecza pojawiły się też nowe próby ujęcia zagadnień związanych z synodami, między innymi ukazujące statuty synodalne jako instrument formacji duchownych oraz chrystianizacji (katechizacji) wiernych ${ }^{12}$. Ciągle jednak wiele kwestii - i to podstawowych - nie doczekało się wyczerpującego opracowania. Do dnia dzisiejszego nie ma pełnej edycji statutów synodalnych niektórych polskich diecezji (np. diecezji krakowskiej). Brak też odpowiadającego obecnemu stanowi wiedzy wykazu synodów wielu średniowiecznych diecezji, gdyż wiąże się to z koniecznością przeprowadzenia dokładnej kwerendy źródłowej. Nic więc dziwnego, że część historyków woli korzystać z wydanych już źródeł i kreślić na ich podstawie mniej lub bardziej udane wizje historiograficzne, aniżeli prowadzić badania podstawowe w zakresie poszukiwania nowych źródeł na temat życia synodalnego poszczególnych Kościołów partykularnych. O tym jednak, że takie poszukiwania są konieczne, niech świadczy przykład diecezji poznańskiej. Jeden z najwybitniejszych znawców problematyki synodalnej w Polsce Jakub Sawicki, wydając w 1952 r. tom poświęcony synodom diecezji poznańskiej dla omawianego okresu, odnotował jedynie cztery synody $(1420,1429,1430 / 1431,1441)^{13}$. Z kolei ks. Józef Nowacki, publikując 12 lat później drugi tom monografii archidiecezji poznańskiej, na którym opiera się wydany w 2004 r. tom zatytułowany Synody diecezji poznańskiej w latach 1251-1738, wymienił aż dziewięć synodów dla tego okresu (1420, 1421, 1424, 1430, $1430 / 1431,1432,1437,1441,1442)^{14}$, poświadczonych w dobrze mu znanych aktach biskupich i konsystorskich, z których tylko częściowo korzystał wcześniej Jakub Sawicki. Natomiast Elżbieta Knapek, poprzez analizę znanych już wcześniej i różnie interpretowanych źródeł, ustaliła ostatnio odbycie kolejnego synodu poznańskiego zwołanego przez biskupa Piotra Wysza w 1413 r., zamykając tym samym długą dyskusję na temat datacji wspomnianego synodu, znanego jedynie $z$ wydanych na nim statutów ${ }^{15}$. Nie tylko więc odkrywanie nowych źródeł, ale również reinterpretacja źródeł już znanych przynosi nowe ustalenia, które nie wszyscy historycy uwzględniają w swoich publikacjach, wybiórczo korzystając z literatury przedmiotu i powielając często nieaktualne poglądy. Tak było z obecną przez lata w polskiej historiografii tezą o synodzie krakowskim biskupa Wojciecha Jastrzębca z 1423 r., który

\footnotetext{
11 P. Krafl, Synody a synodálni zákonodártvi ve středovýchodni Evropě. Přehled bádání za poslednich patnáct let, „Český Časopis Historický”, 111/2013, nr 1, s. 117-143.

12 Zob. O. Pontal, Le rôle du synode diocésain et des statuts synodaux dans la formation du clergé, w: Les évèques, les clercs et le roi (1250-1300), Toulouse 1972, s. 337359; J. Helmrath, Partikularsynoden, op. cit., s. $165-169$ (autor skupił się tu na treści statutów synodalnych w odniesieniu do wykształcenia duchownych i katechizacji wiernych); A. Radzimiński, Udział zakonu krzyżackiego w procesie ewangelizacji Prus. Uwagi na podstawie ustawodawstwa synodalnego, „Zapiski Historyczne”, 60/2005, z. 1, s. 7-26; K. Ożóg, Kleine Pastoralkompendien in den spätmittelalterlichen Synodalstatuten Polens, w: Partikularsynoden, op. cit., s. 215-237; S. Bylina, Statuty synodalne jako instrument chrystianizacji wsi w późnym średniowieczu, w: Sacri canones servandi sunt. Ius canonicum et status ecclesiae saeculis XIII-XV, red. P. Krafl, Praha 2008, s. 271-284.

13 J. Sawicki, Concilia Poloniae. Źródła i studia krytyczne, t. 7: Synody diecezji poznańskiej i ich statuty, Poznań 1952, s. IX, 7-42.

14 J. Nowacki, Synody diecezji poznańskiej w latach 1252-1738, Poznań 2004, s. 12-29.

15 E. Knapek, Piotr Wysz wobec kryzysu Kościoła, w: Ecclesia semper reformanda, op. cit., s. 301-310.
} 
w rzeczywistości odbył się w 1420 r., o czym Jakub Sawicki pisał w pełni przekonująco już w latach czterdziestych minionego stulecia ${ }^{16}$, ale na co nie zwracano uwagi przez kilkadziesiąt lat. Przedstawione tu uwagi nie zmieniają faktu, że nie brak badaczy, którzy poruszają w swoich pracach problematykę synodalną oraz wydają nowe źródła do dziejów synodów ${ }^{17}$, a inni starają się śledzić najnowsze badania nad synodami, co potem znajduje odzwierciedlenie w ich publikacjach, czego dobrym przykładem były wyjątkowo starannie przygotowywane prace nieżyjącej już Izabeli Skierskiej ${ }^{18}$.

Brak wyczerpujących studiów na temat życia synodalnego w późnośredniowiecznych diecezjach polskich, niemieckich i pruskich nie oznacza, że badania w tym zakresie nie są prowadzone. Wśród prac dotyczących późnośredniowiecznych synodów frankońskich, jakie ukazały się drukiem w minionym ćwierćwieczu, poza wcześniejszymi artykułami Petera Johannka i Petera Langa ${ }^{19}$, a także wzmiankami źródłowymi o synodach zawartymi w biogramach biskupów wydanych już wcześniej w ramach projektu badawczego „Germania Sacra”20, najważniejszą pracą jest artykuł Helmuta Flacheneckera poświęcony synodom frankijskim przełomu XIV i XV wieku i ogłoszonym na nich statutom synodalnym ${ }^{21}$. Pewne odniesienia do ruchu synodalnego w diecezjach frankońskich znajdują się w pracy Birgit Studt na temat reformy Kościoła niemieckiego za pontyfikatu papieża Marcina $\mathrm{V}^{22}$. Z kolei na temat średniowiecznych synodów krzyżackich w omawianym okresie pisali ks. Jan Wiśniewski, Arno Mentzel-Reuters oraz Andrzej Radzimiński²3. Poza tym w 2010 r. bp Julian Wojtkowski

16 J. Sawicki, Concilia Poloniae, t. 4: Najdawniejsze statuty synodalne diecezji chetmskiej z XV w., Lublin 1948, s. 68 i nn. Zob. także W. Kłapkowski, Działalność kościelna biskupa Wojciecha Jastrzębca, Warszawa 1932, s. 75 nn.; L. Zygner, Synody diecezjalne metropolii gnieźnieńskiej na przełomie XIV i XV wieku (Gniezno - Kraków Płock - Poznań - Włocławek), w: Kultura prawna w Europie Środkowej, red. A. Barciak, Katowice 2006, s. 187: K. Ożóg, Biskupa Wojciecha Jastrzębca „,paterna sollicitudo” o Kościól krakowski. Statuty synodalne z roku 1420 , w: Wojciech Jastrzębiec - w stużbie monarchii i Kościoła, red. B. Czwojdrak, F. Kiryk, J. Sperka, Katowice 2018, s. 148 , przyp. 14 .

17 M. Czyżak, A. Radzimiński, Earliest Synod Statutes of John Marienau, Bishop of Chetmno, from the First Half of 15th Century, „Quaestiones Medii Aevii Novae”, 24/2019, s. 111-135.

18 Mam tu na myśli zwłaszcza dwie prace Izabeli Skierskiej: Obowiązek mszalny w średniowiecznej Polsce, Warszawa 2003 oraz Sabbatha sanctifices. Dzień święty w średniowiecznej Polsce, Warszawa 2008.

19 P. Johannek, Zur kirchlischen Reformtätigkeit Bischof Lamprechts von Brunn, ,Bericht des Historischen Vereins für die Pflege des Geschichte des ehemaligen Fürstbistums Bamberg”, 102/1966, s. 235-256; P.T. Lang, Die Synoden in der alten Diözese Würzburg, ,Rottenburger Jahrbuch für Kirchengeschichte”, 5/1986, s. 71-84.

20 E. von Guttenberg, Das Bistum Bamberg, t. 1, Berlin 1937, s. 238, 243, 260; A. Wendehorst, Das Bistum Würzburg, cz. 2: Die Bischofsreihe von 1254 bis 1455, Berlin 1969, s. 138, 182-183; idem, Das Bistum Eichstätt, t. 1: Die Bischofsreihe bis 1535, Berlin 2006, s. 199, 210.

${ }^{21}$ H. Flachenecker, Das beständige Bemühen um Reform. Zu Synoden und Synodalstatuten in den fränkischen Bistümern des 14./15. Jahrhunderts, w: Partikularsynoden, op. cit., s. 55-75.

22 B. Studt, Papst Martin V. (1417-1431) und die Kirchenreform in Deutschland, Köln-Weimar-Wien 2004, s. 283 i nn.

23 J. Wiśniewski, Średniowieczne synody pomezańskie. Dekanat sztumski (1601-1821), Elbląg 1999, s. 7-82; A. Mentzel-Reuters, Preussische Diözesanstatuten und Reformen im Deutschen Orden, w: Von der Ordnung zur Norm. Statuten in Mittelalter und Früher Neuzeit, red. G. Drossnach, Paderborn 2010, s. 55-70; A. Radzimiński, Udziat zakonu, op. cit., s. 7-26; idem, Synodalstatuten im Deutschordensland Preußen, w: Partikularsynoden, op. cit., s. 157-176; idem, Ustawodawstwo synodów diecezjalnych w państwie zakonu krzyżackiego w Prusach. Uwagi do problemu, w: Ecclesia - cultura - potestas. Studia z dziejów kultury i społeczeństwa, red. P. Kras, A. Januszek, A. Nalewajek, W. Polak, Kraków 2006, s. 145-155; idem, Prawo kościelne oraz procesy ewangelizacyjne w państwie zakonu krzyżackiego w Prusach, w: Sacri canones servandi sunt, op. cit., s. 258-270; idem, Kościót i duchowieństwo $w$ średniowieczu. Polska i państwo zakonu krzyżackiego w Prusach, Toruń 2012, s. 259-272 (statuty synodalne w państwie zakonu krzyżackiego w Prusach). Zob. także W. Zawadzki, Model kapłana pomezań- 
opublikował polskie tłumaczenie statutów synodalnych diecezji pruskich wydanych przez ks. Franza Hiplera w 1899 r. ${ }^{24}$ Natomiast w 2019 r. Marta Czyżak i Andrzej Radzimiński wydali zbiór statutów synodalnych biskupa chełmińskiego Jana Marienau z 1438 r., biskupa Stefana z Nidzicy z 1481 r. i biskupa Mikołaja Chrapickiego z 1498 r., zachowany w jednym z rękopisów Biblioteki Uniwersytetu Mikołaja Kopernika w Toruniu ${ }^{25}$, które to statuty znano wcześniej jedynie ze streszczeń ${ }^{26}$. Na temat synodów metropolii gnieźnieńskiej, poza wcześniejszymi pracami ks. Ignacego Subery i bpa Walentego Wójcika ${ }^{27}$, ukazało się w minionym ćwierćwieczu ponad 30 szczegółowych opracowań ${ }^{28}$, a ponadto syntezy oraz

skiego $w X V w . w$ świetle ustawodawstwa synodalnego, w: Studia z dziejów diecezji pomezańskiej w 775. rocznice jej utworzenia, red. J. Liguz, Pelplin 2020, s. 137-148.

24 Statuty synodalne warmińskie, sambijskie, pomezańskie, chetmińskie oraz prowincjonalne ryskie, thum. J. Wojtkowski, Olsztyn 2010.

25 M. Czyżak, A. Radzimiński, Earliest Synod Statutes, op. cit., s. 119-134 (tekst źródłowy).

26 F. Hipler, Die culmischen Diöcesansynode, „Pastoralblatt für die Diöcese Ermland”, 36/1898, s. 63-65; Constitutiones synodales necnon, op. cit., s. 13-19.

27 I. Subera, Synody prowincjonalne arcybiskupów gnieźnieńskich. Wybór tekstów ze zbioru Jana Wężyka z r. 1761, wyd. 2, Warszawa 1981; W. Wójcik, Ze studiów nad synodami polskimi, Lublin 1982; idem, Statuty synodu archidiecezji gnieźnieńskiej z 1414 r, red. J. Krukowski, Lublin 1988, „Kościół i Prawo”, t. 5, s. 11-39.

28 Zob. np. Z. Jakubowski, Ustawodawstwo synodalne arcybiskupów gnieźnieńskich z lat 1420-1423 jako wyraz stosunku polskiej hierarchii kościelnej do husytyzmu. Wstęnna charakterystyka zjawiska i perspektywy badań, „Studie o rukopisech”, 29/1992, s. 69-78; A. Krawiec, Problematyka matżeńska w średniowiecznym ustawodawstwie synodalnym Kościoła polskiego, w: Docendo discimus. Studia historyczne ofiarowane profesorowi Zbigniewowi Wielgoszowi w siedemdziesiąta rocznicę urodzin, red. K. Kaczmarek, J. Nikodem, Poznań 2000, s 247-284; W. Mrozowicz, Breslauer Synoden des Mittelalters und ihre Widerspiegelung in den Quellen. Ausgewähle Probleme, w: Partikularsynoden, op. cit., s. 275-287; K. Ożóg, Kleine Pastoralkompendien, op. cit., s. 215-237; idem, Matżeństwo w polskim ustawodawstwie synodalnym wieków średnich, w: Manželstvi v pozdním středověku. Rituály a obyčeje, red. P. Krafl, M. Nodl, Praha 2014, s. 15-33; idem, Biskupa Wojciecha Jastrzębca, op. cit., s. 145-160; M. Derwich, Synoden und Ordensreform im spätmittelalterlichen Polen, w: Partikularsynoden, op. cit., s. 199-214; T. Wünsch, Das Reformprogramm des Krakauer Bischofs Petrus Wysz 1391-1412. Mit Neuedition der 22-Punkte-Liste „De reformatione ecclesie”, w: Kirchliche Reformimpulse des 14./15. Jahrhunderts in Ostmitteleuropa, red. W. Eberhard, F. Machilek, Köln-Weimar-Wien 2006, s. 157-178; S. Bylina, Statuty synodalne, op. cit., s. 271-284; M.M. Grynicz, Aktywność reformatorska arcybiskupa gnieźnieńskiego Jarosława z Bogorii na przykładzie jego działalności ustawodawczej, w: Ecclesia semper reformanda, op. cit., s. 273-283; E. Knapek, Piotr Wysz wobec kryzysu, op. cit., s. 301-310; S. Konarska-Zimnicka, , Nie szata zdobi człowieka”. Polskie statuty synodalne w walce o skromność ubioru duchownych, w: Ecclesia semper reformanda, op. cit., s. 443-464; B. Wojciechowska, Duchowni włóczędzy w świetle ustawodawstwa synodalnego metropolii gniénnieńskiej, w: Samotrzeć, w kompanii czy z orszakiem. Społeczne aspekty podróżowania $w$ średniowieczu i w czasach nowożytnych, red. M. Saczyńska, E. Wółkiewicz, Warszawa 2012, s. 53-67; eadem, Małżeństwo w ustawodawstwie synodalnym Kościoła polskiego w późnym średniowieczu, „Czasopismo Prawno-Historyczne”, 67/2015, z. 1, s. 21-29; L. Zygner, Kodyfikacja płocka biskupa Jakuba Kurdwanowskiego z przełomu XIV i XV wieku, w: W mazowieckiej przestrzeni kulturowej. Prace ofiarowane w 80. rocznicę urodzin Profesora Ryszarda Juszkiewicza, red. B. Dymek, Warszawa 2007, s. 33-79; idem, Nieznany synod prowincjonalny arcybiskupa Dobrogosta Nowodworskiego z 1398 roku, „Studia Mazowieckie”, 7(14)/2012, nr 3, s. 83-93; idem, Działalność synodalna arcybiskupa Mikołaja Kurowskiego, „Roczniki Historyczne", 78/2012, s. 107-125; idem, Die Kinder in den mittelalterlichen Synodalstatuten Polens. Eine Skizze, „Documenta Pragensia”, 31/2012, s. 103-118; idem, W sprawie synodów arcybiskupa gnieźnieńskiego Janusza Suchegowilka (1374-1382), w: Kościót i duchowieństwo w średniowiecznej Polsce $i$ na obszarach sąsiednich, red. R. Biskup, A. Radzimiński, Toruń 2013, s. 223-242; idem, W sprawie synodu prowincjonalnego w Uniejowie w 1414 r., w: Si vis pacem, para bellum. Bezpieczeństwo i polityka Polski. Księga jubileuszowa ofiarowana profesorowi Tadeuszowi Dubickiemu, red. R. Majzer, Częstochowa-Włocławek 2013, s. 1136-1144; idem, Działalność synodalna arcybiskupa Mikołaja Trąby, w: Piśmienność pragmatyczna - edytorstwo źródel historycznych archiwistyka. Studia ofiarowane Profesorowi Januszowi Tandeckiemu w sześćdziesiata piata rocznicę urodzin, red. R. Czaja, K. Kopiński, Toruń 2015, s. 213-231; idem, Reforma prawa partykularnego metropolii gnieźnieńskiej w XV i na początku XVI wieku oraz jej wpływ na ustawodawstwo diecezji wileńskiej i żmudzkiej, w: Kultūra - ekonomika - visuomenè: squeika ir pokyčiai viduramžiais ir ankstyvaisiais naujaisiais laikais Baltijos rytinëje pakrantejje, red. M. Ščavinkas, Klaipèda 2015, s. 112-134; idem, Kilka uwag w sprawie synodów diecezji lubuskiej 
prace porównawcze autorstwa ks. Wojciecha Góralskiego, Wacława Uruszczaka, kard. Pétera Erdö, ks. Józefa Nowackiego, Thomasa Wünscha, Pavla Krafla i piszącego te słowa ${ }^{29}$.

Przedstawiona pokrótce najnowsza literatura przedmiotu oraz opublikowane do tej pory edycje ustaw synodalnych pozwalają na zestawienie znanych dziś synodów prowincjonalnych i diecezjalnych, które odbyły się w omawianym okresie oraz wydanych uchwał synodalnych. Z kolei w dalszej części, idąc za Pavlem Kraflem, który w swoim artykule dotyczącym synodów praskich, ołomunieckich, wrocławskich i litomyskich, zwrócił uwagę na następujące kwestie: częstotliwość zwoływania synodów, terminy i miejsce obrad synodalnych, przewodniczenie obradom, akta i protokoły synodów, statuty synodalne, wpływ ustawodawstwa prowincjonalnego na ustawodawstwo diecezjalne, a także problem publikowania i obowiązku posiadania statutów przez duchownych ${ }^{30}$, chciałem niektóre podjęte tu problemy ukazać na tle porównawczym. Pamiętając jednak o ograniczonych ramach niniejszego szkicu, skoncentruję uwagę na następujących zagadnieniach: częstotliwość zwoływania synodów, stosunek biskupów do instytucji synodów, ciągłość w ustawodawstwie synodalnym poszczególnych diecezji i związaną z tym rolę „ksiąg synodalnych”, zależności między zbiorami uchwał synodalnych różnych diecezji i prowincji kościelnych, przebieg synodów i ich liturgia, statuty synodalne jako instrument formacji duchownych i katechizacji wiernych.

\section{Wykazy synodów i zachowanych statutów synodalnych}

Opierając się na dotychczasowych badaniach, a także na wcześniejszych pracach innych autorów, poniżej zamieszczam tabelaryczne zestawienie synodów i ustaw synodalnych dla omawianych prowincji kościelnych w latach 1378-1449. W przypadku synodów diecezji frankońskich odwołuję się głównie do ustaleń Helmuta Flacheneckera ${ }^{31}$. Opracowany przez

w średniowieczu, w: Memoria viva. Studia historyczne poświęcone pamięci Izabeli Skierskiej (1967-2014), Warszawa-Poznań 2015, s. 415-423; idem, Działalność synodalna arcybiskupa Wojciecha Jastrzębca (próba retrospekcji i reinterpretacji), „Studia Mazowieckie”, 10(24)/2015, nr 3, s. 59-82; idem, Wkład Kościoła płockiego i wrocławskiego w życie synodalne metropolii gnieźnieńskiej końca XIV i pierwszej połowy XV wieku, „Studia Mazowieckie”, 10(24)/2015, nr 3, s. 83-117.

29 W. Góralski, Wprowadzenie do historii ustawodawstwa synodalnego w Polsce, Lublin 1991; W. Uruszczak, Ustawodawstwo synodów Kościoła katolickiego w Polsce w XIII i XIV wieku, „Czasopismo Prawno-Historyczne”, 51/1999, z. 1-2, s. 133-148; P. Erdö, Synodalbücher der Kirchenprovinzen von Gnesen, Prag und Salzburg. Zu den Erscheinungsformen einer spätmittelalterlichen literarischen Gattung, "Rivista Internazionale di Dritti Comune", 10/1999, s. 9-36; J. Nowacki, Synody diecezji, op. cit.; T. Wünsch, Partikularsynoden als Normierungsinstanzen am Vorabend der Reformation (Beispiele aus Böhmen-Mähren, Schlesien und Polen), w: Partikularsynoden, op. cit., s. 289-306; P. Krafl, Přehled provinciálních synod Hnězdna z let 1206-1503, „Slovanské historické studie”, 25/1999, s. 5-34; idem, Provinciální synody hnězdenské církevní provincie do začátku 16. století, „Prawo Kanoniczne", 43/2000, nr 1-2, s. 37-78; idem, Polské provinciální synody 13.-15. století, Praha 2016; L. Zygner, Synody diecezjalne, op. cit., s. 165-226; idem, Instytucja synodu diecezjalnego w życiu Kościoła płockiego (XIII-XVIII wiek), w: Mazowsze w retrospektywie badawczej. Dynastie, instytucje, społeczeństwo, red. W. Graczyk, J.M. Marszalska, B. Dźwigała, Kraków 2016, s. 123-152. Pomijam natomiast w tym miejscu publikacje ks. Stanisława Tymosza. Chodzi tu głównie o dwie publikacje wspomnianego autora: Gnesener Provinzial- und Diözesansynoden im 14. und 15. Jahrhundert - Ein Überblick, w: Partikularsynoden, op. cit., s. 177-198; idem, Ewolucja kościelnego prawa polskiego w świetle kodyfikacji do XIX wieku, Lublin 2008, które niewiele wniosły do wcześniejszych badań i spotkały się z dezaprobatą środowiska naukowego. Zob. W. Uruszczak, Z takim sposobem uprawiania nauki zgodzić się nie można! Twórczość historyczno-prawna ks. dra hab. Stanisława Tymosza z lat 2003-2008, „Studia z Dziejów Państwa i Prawa Polskiego", 13/2010, s. 265-284.

30 P. Krafl, Wybrane aspekty życia synodalnego w diecezjach praskiej, ołomunieckiej, wrocławskiej i litomyskiej do końca XV wieku. Porównanie, ,Śląski Kwartalnik Historyczny Sobótka”, 54/1999, s. 467-482.

31 H. Flachenecker, Das beständige, op. cit., s. 75. 
niego wykaz synodów uzupełniłem jedynie o synod, który zapewne odbył się w Eichstätt w 1435 r., a na którym kazanie synodalne głosił kanonik katedralny i licencjat dekretów Johann von Eyb ${ }^{32}$, a także o synod bamberski z 1378 r. ${ }^{33}$ Z kolei wykaz synodów w diecezjach pruskich oparłem na ustaleniach Andrzeja Radzimińskiego, uzupełniając je wydanymi ostatnio statutami chełmińskimi z 1438 r. $^{34}$ Natomiast badania prowadzone nad synodami prowincjonalnymi gnieźnieńskimi pozwoliły mi na uzupełnienie i skorygowanie wykazu synodów podawanych w dotychczasowej literaturze. W przeciwieństwie do Pavla Krafla, który zestawił ostatnio synody prowincjonalne gnieźnieńskie późnego średniowiecza, w niniejszym wykazie umieszczam również synod prowincjonalny z 1402 r., który przez czeskiego badacza był uznany jedynie za zjazd biskupów ${ }^{35}$, natomiast w roku 1441 - odwołując się do wcześniejszych ustaleń Stefana Haina ${ }^{36}$ - przyjmuję obrady jednego, a nie dwóch synodów prowincjonalnych ${ }^{37}$. Z kolei zestawienie synodów diecezjalnych metropolii gnieźnieńskiej opieram na własnych publikacjach ${ }^{38}$, w których znajdują się odniesienia do starszej literatury przedmiotu, a także na pracach ks. Henryka Karbownika, ks. Józefa Nowackiego, Zofii Kowalskiej, Elżbiety Knapek, ks. Bolesława Kumora, Marii Koczerskiej, Krzysztofa Ożoga i Wiktora Szymborskiego ${ }^{39}$. Do wykazu uchwał synodalnych dołączam statuty synodalne gnieźnieńskie z 1414 r., odkryte już w okresie międzywojnia przez ks. Henryka Likowskiego, ale z różnych względów niedostępne dla badaczy przez dziesiątki lat i opublikowane dopiero pod koniec lat osiemdziesiątych XX wieku przez bpa Walentego Wójcika ${ }^{40}$.

\footnotetext{
32 A. Wendehorst, Das Bistum Eichstätt, op. cit., s. 199.

33 P. Johannek, Zur kirchlischen, op. cit., s. 248-249. Zob. także E. von Guttenberg, Das Bistum Bamberg, op. cit., s. 82; H. Flachenecker, F. Rapp, Lamprecht von Brunn, w: Die Bischöfe des Heiligen Römischen Reiches 1198 bis 1448. Ein biographisches Lexikon, red. E. Gatz, C. Brodkorb, Berlin 2001, s. 184; B. Studt, Papst Martin V., op. cit., s. 278.
}

34 M. Czyżak, A. Radzimiński, Earliest Synod, op. cit., s. 119-130.

35 P. Krafl, Polské provinciální synody, op. cit., s. 66-67, przyp. 64. Por. L. Zygner, Działalność synodalna arcybiskupa Mikołaja Kurowskiego, op. cit., s. 114. Zob. także moją recenzję pracy Pavla Krafla w: „Kwartalnik Historyczny", 125/2018, nr 1, s. 117.

36 S. Hain, Wincenty Kot prymas Polski 1436-1448, Poznań 1948, s. 150-151.

37 Por. P. Krafl, Polské provinciálni synody, op. cit., s. 125-126.

38 Chodzi o prace wymienione w przyp. 17 i 18.

39 H. Karbownik, Wiadomość o synodzie diecezji krakowskiej z 1443 roku, „Roczniki Teologiczno-Kanoniczne”, 30/1983, z. 5, s. 158-159; J. Nowacki, Synody diecezji, op. cit., s. 12-29; Z. Kowalska, Stanisław Ciołek († 1437), podkanclerzy królewski, biskup poznański, poeta dworski, Kraków 1993, s. 73-78; E. Knapek, Piotr Wysz, op. cit., s. 310; B.S. Kumor, Dzieje diecezji krakowskiej do roku 1795, t. 2, Kraków 1999, s. 125-132; M. Koczerska, Oleśnicki Zbigniew, w: Polski Słownik Biograficzny, t. 23, Wrocław 1978, s. 782; eadem, Zbigniew Oleśnicki i Kościót krakowski w czasach jego pontyfikatu (1423-1455), Warszawa 2004, s. 373, 434; K. Ożóg, , Pastor bonus ”-duszpasterskie zabiegi biskupa Zbigniewa Oleśnickiego w diecezji krakowskiej, w: Zbigniew Oleśnicki książę Kościoła i mąż stanu, red. F. Kiryk, Z. Noga, Kraków 2006, s. 159-161; W. Szymborski, Odpusty w średniowiecznej Polsce, Kraków 2011, passim.

40 W. Wójcik, Statuty synodu, op. cit., s. 11-12 (tu opisana w skrócie historia prac nad wydaniem tych statutów). Publikacji tej nie uwzględnił w podsumowaniu stanu badań nad średniowiecznym ustawodawstwem synodalnym w Polsce ks. Wojciech Góralski (Stan badań, op. cit., s. 25-26), ja zaś, przygotowując przed laty artykuł na temat synodów diecezjalnych metropolii gnieźnieńskiej przełomu XIV i XV wieku (L. Zygner, Synody diecezjalne, op. cit., s. 174), ciągle szukałem śladów po rękopisie, o którym pisał ks. Henryk Likowski, natomiast pracy bpa Walentego Wójcika nie znałem. Dopiero w trakcie dalszych badań dotarłem do niej i zamieszczam ją obecnie w wykazie statutów synodalnych archidiecezji gnieźnieńskiej. 
Tab. 1. Zestawienie synodów diecezji frankońskich

\begin{tabular}{|c|c|c|c|}
\hline Data synodu & $\begin{array}{c}\text { Miejsce } \\
\text { Obrad }\end{array}$ & $\begin{array}{c}\text { Biskup [inny duchowny, który } \\
\text { przewodniczył obradom w imieniu } \\
\text { biskupa] }\end{array}$ & $\begin{array}{l}\text { Wydane uchwały } \\
\text { (statuty) }\end{array}$ \\
\hline \multicolumn{4}{|c|}{ Diecezja Bamberg } \\
\hline 10 X 1378 r. & Bamberg & Lamprecht von Brunn & $\begin{array}{l}\text { statuty - brak edycji (Schloßbi- } \\
\text { bliothek Pommersfelden, Cod. } \\
179)\end{array}$ \\
\hline $1387 \mathrm{r}$. & Bamberg & Lamprecht von Brunn & brak \\
\hline 2 VI 1394 r. & Bamberg & Lamprecht von Brunn & brak \\
\hline 1402 r. & Bamberg & Albrecht von Wertheim & $\begin{array}{l}\text { statuty - brak edycji (Herzog- } \\
\text {-August-Bibliothek Wolfenbüttel, } \\
\text { Cod. 2714) }\end{array}$ \\
\hline $28 \mathrm{~V} 1433 \mathrm{r}$ & Bamberg & Anton von Rotenhan & $\begin{array}{l}\text { BS, s. 48-85 (pod błędna data } \\
\text { 1431) }\end{array}$ \\
\hline 16-17 III 1448 r. & Bamberg & Anton von Rotenhan & brak \\
\hline \multicolumn{4}{|c|}{ Diecezja Eichstätt } \\
\hline $21 \times 1434$ r. & Eichstätt & Albrecht von Hohenrechberg & NCB, s. 193-198 \\
\hline $1435 \mathrm{r}$. & Eichstätt & Albrecht von Hohenrechberg & brak \\
\hline $1442 \mathrm{r}$. & Eichstätt & Albrecht von Hohenrechberg & statuty (?) \\
\hline $11 \times 1447 \mathrm{r}$. & Eichstätt & Johann von Eich & CBE, s. 110-112, 114-116, 118-123 \\
\hline \multicolumn{4}{|c|}{ Diecezja Würzburg } \\
\hline $1 \mathrm{IX} 1407 \mathrm{r}$. & Würzburg & Johann von Egloffstein & SH, s. 212-229 \\
\hline 23 X $1411 \mathrm{r}$. & Würzburg & Johann von Egloffstein & SH, s. 229-233 \\
\hline 14 IX 1446 r. & Würzburg & Gottfried von Limpurg & SH, s. 233-273 \\
\hline
\end{tabular}

BS - Die Bamberger Synoden; CBE - J.G. Suttner, Versuch einer Conciliengeschichte des Bisthums Eichstätt; NCB - J.G. Suttner, Nachträge zur Conciliengeschichte; SH - Synodicon Herbipolense.

Tab. 2. Zestawienie synodów diecezji pruskich

\begin{tabular}{|c|c|c|c|}
\hline Data synodu & $\begin{array}{l}\text { Miejsce } \\
\text { Obrad }\end{array}$ & $\begin{array}{c}\text { Biskup [inny duchowny, który } \\
\text { przewodniczył obradom w imieniu } \\
\text { biskupa] }\end{array}$ & $\begin{array}{l}\text { Wydane uchwały } \\
\text { (statuty) }\end{array}$ \\
\hline \multicolumn{4}{|c|}{ Synody prowincjonalne } \\
\hline Ok. 24 IV 1427 r. & Elbląg & biskupi pruscy & CSW, s. 301-306 \\
\hline 25 I - 6 II 1428 r. & Ryga & Henning Scharpenberg & CSW, s. 307-340 \\
\hline $18-25$ II 1437 r. & Ryga & Henning Scharpenberg & CSW, s. 357-362 \\
\hline \multicolumn{4}{|c|}{ Diecezja chełmińska } \\
\hline 19 III 1438 r. & Chełmża & Jan Marienau & CR, s. 119-130 \\
\hline \multicolumn{4}{|c|}{ Diecezja pomezańska } \\
\hline $26 \mathrm{~V} 1411 \mathrm{r}$. & Kwidzyn & Jan Ryman & CSW, s. 273-282 \\
\hline $10 \mathrm{~V} 1418 \mathrm{r}$ & Kwidzyn & Gerhard Stolpman & $\begin{array}{l}\text { potwierdzenie statutów z } 1411 \mathrm{r} \text {. } \\
(\mathrm{CSW}, \mathrm{s} .282-283)\end{array}$ \\
\hline 23 IX 1428 r. & Kwidzyn & Jan Mewe & CSW, s. 283-284 \\
\hline 22 IX $1440 \mathrm{r}$. & Kwidzyn & Kaspar Linke & CSW, s. 285-287 \\
\hline \multicolumn{4}{|c|}{ Diecezja warmińska } \\
\hline $\begin{array}{l}1373 / 1401 \\
\text { trzy synody }\end{array}$ & $\begin{array}{l}\text { Lidzbark War- } \\
\text { miński (?) }\end{array}$ & Henryk Sorbom & CSW, s. 1-10 \\
\hline $12 \mathrm{~V} 1449 \mathrm{r}$ & $\begin{array}{l}\text { Lidzbark } \\
\text { Warmiński }\end{array}$ & Franciszek Kuhschmalz & CSW, s. 14-22 \\
\hline
\end{tabular}




\begin{tabular}{|l|l|l|l|}
\hline \multicolumn{1}{|c|}{ Data synodu } & \multicolumn{1}{|c|}{$\begin{array}{c}\text { Miejsce } \\
\text { Obrad }\end{array}$} & $\begin{array}{c}\text { Biskup [inny duchowny, który } \\
\text { przewodniczył obradom w imieniu } \\
\text { biskupa] }\end{array}$ & \multicolumn{1}{|c|}{$\begin{array}{c}\text { Wydane uchwały } \\
\text { (statuty) }\end{array}$} \\
\hline Diecezja sambijska & Królewiec & Henryk Seefeld & brak \\
\hline $\begin{array}{l}1387 / 1414 \\
\text { trzy synody }\end{array}$ & Królewiec & Jan Saalfeld & brak \\
\hline $1416 / 1425$ & Królewiec & Michał Junge & CSW, s. 261-271 \\
\hline Ok. $1427 \mathrm{r}$. & Królewiec & Michał Junge & CSW, s. 271-272 \\
\hline 21 II $1441 \mathrm{r}$. & \multicolumn{2}{|l}{}
\end{tabular}

CR - M. Czyżak, A. Radzimiński, Earliest Synod Statutes; CSW - Constitutiones synodales Warmienses, Sambienses, Pomesanienses, Culmenses necnon provinciales Rigenses.

Tab. 3. Zestawienie synodów metropolii gnieźnieńskiej

\begin{tabular}{|c|c|c|c|}
\hline Data synodu & $\begin{array}{c}\text { Miejsce } \\
\text { Obrad }\end{array}$ & $\begin{array}{c}\text { Biskup [inny duchowny, który } \\
\text { przewodniczył obradom w imieniu } \\
\text { biskupa] }\end{array}$ & $\begin{array}{c}\text { Wydane uchwały } \\
\text { (statuty) }\end{array}$ \\
\hline \multicolumn{4}{|c|}{ Synody prowincjonalne } \\
\hline 13 XI $1398 \mathrm{r}$. & Kalisz & Dobrogost Nowodworski & brak \\
\hline 29 XI 1402 r. & Łęczyca & Mikołaj Kurowski & brak \\
\hline 18-20 IV $1406 \mathrm{r}$ & Kalisz & Mikołaj Kurowski & ACS, s. 221-222 \\
\hline 27 I 1409 r. & Kalisz & Mikołaj Kurowski & brak \\
\hline 5 VIII $1414 \mathrm{r}$. & Uniejów & Mikołaj Trąba & brak \\
\hline $\begin{array}{l}15-22 \text { I } 1420 \mathrm{r} \\
15-25 \text { IX } 1420 \mathrm{r} .\end{array}$ & $\begin{array}{l}\text { Wieluń } \\
\text { Kalisz }\end{array}$ & $\begin{array}{l}\text { Mikołaj Trąba } \\
\text { Mikołaj Trąba }\end{array}$ & SSWK, s. 1-121 \\
\hline 24-27 VIII $1422 \mathrm{r}$. & Łęczyca & Mikołaj Trąba & brak \\
\hline $6 \mathrm{~V} 1425 \mathrm{r}$. & Łęczyca & Wojciech Jastrzębiec & SSW, s. CLXIX-CLXX \\
\hline przed 19 III $1430 \mathrm{r}$. & Łęczyca & Wojciech Jastrzębiec & brak \\
\hline po 10 III $1433 \mathrm{r}$. & Łęczyca & Wojciech Jastrzębiec & brak \\
\hline $26 \mathrm{~V} 1435 \mathrm{r}$ & Łęczyca & Wojciech Jastrzębiec & brak \\
\hline 23-27 IV $1440 \mathrm{r}$ & Łęczyca & Wincenty Kot & brak \\
\hline 7/8-11 V $1441 \mathrm{r}$ & Łęczyca & Wincenty Kot & brak \\
\hline 23 IV 1442 r. & Piotrków & Wincenty Kot & brak \\
\hline \multicolumn{4}{|c|}{ Archidiecezja gnieźnieńska } \\
\hline VI/VII $1408 \mathrm{r}$. & Łęczyca & Mikołaj Kurowski & CP, t. 5, s. 257-268 \\
\hline VI $1414 \mathrm{r}$. & Uniejów & Mikołaj Trąba & SSAG, s. 22-38 \\
\hline ok. $1430 / 1431 \mathrm{r}$. & Kazimierz & Wojciech Jastrzębiec & brak \\
\hline $\begin{array}{l}16 \text { I } 1446 \mathrm{r} . \\
18-19 \text { XII } 1446 \mathrm{r} .\end{array}$ & $\begin{array}{l}\text { Łęczyca } \\
\text { Gniezno }\end{array}$ & Wincenty Kot & brak \\
\hline \multicolumn{4}{|c|}{ Diecezja krakowska } \\
\hline 29 IX - 2 X 1394 r. & Kraków & Piotr Wysz & OPP, s. 31-41 \\
\hline 29 IX 1396 r. & Wiślica & Piotr Wysz & SPPP, t. 4, s. 53-59 \\
\hline $\begin{array}{l}\text { 10-11 IX } 1408 \text { r. } \\
1-2 \text { X } 1408 \text { r. }\end{array}$ & $\begin{array}{l}\text { Sandomierz } \\
\text { Kraków }\end{array}$ & $\begin{array}{l}\text { Piotr Wysz } \\
\text { [wikariusz generalny Jan } \\
\text { Szafraniec] }\end{array}$ & SDK, s. 21-27 \\
\hline $1420 \mathrm{r}$. & Kraków & \begin{tabular}{|l} 
Wojciech \\
Jastrzębiec
\end{tabular} & SPPP, t. 4, s. 63-86 \\
\hline 3 I 1432 r. & Kraków & $\begin{array}{l}\text { Zbigniew } \\
\text { Oleśnicki }\end{array}$ & brak \\
\hline
\end{tabular}




\begin{tabular}{|c|c|c|c|}
\hline Data synodu & $\begin{array}{l}\text { Miejsce } \\
\text { Obrad }\end{array}$ & $\begin{array}{c}\text { Biskup [inny duchowny, który } \\
\text { przewodniczył obradom w imieniu } \\
\text { biskupa] }\end{array}$ & $\begin{array}{l}\text { Wydane uchwały } \\
\text { (statuty) }\end{array}$ \\
\hline 8-10 I 1436 r. & Kraków & $\begin{array}{l}\text { Zbigniew } \\
\text { Oleśnicki }\end{array}$ & SSK, s. 43-51 \\
\hline 20 III 1443 r. & Sandomierz & $\begin{array}{l}\text { Zbigniew } \\
\text { Oleśnicki }\end{array}$ & brak \\
\hline po 8 V $1446 \mathrm{r}$. & Kraków & $\begin{array}{l}\text { Zbigniew } \\
\text { Oleśnicki }\end{array}$ & SSK, s. 52-54 \\
\hline \multicolumn{4}{|c|}{ Diecezja lubuska } \\
\hline $21 \mathrm{IV} 1422 \mathrm{r}$. & Fürstenwalde & Jan z Wałdowa & CDB, cz. 1, t. 20, nr 99 \\
\hline \multicolumn{4}{|l|}{ Diecezja płocka } \\
\hline 8 IX 1398 r. & Płock & Jakub z Kurdwanowa & CP, t. 6, s. 181-258 (art. 1-38) \\
\hline $8 \mathrm{XI} 1400 \mathrm{r}$. & Płock & Jakub z Kurdwanowa & brak \\
\hline 1409/1411 r. & Płock & Jakub z Kurdwanowa & brak \\
\hline $1420 / 1421 \mathrm{r}$. & Czerwińsk & Jakub z Kurdwanowa & $\begin{array}{l}\text { statuty /być może promulgowane } \\
\text { dopiero w } 1423 \text { r./- CP, t. 6, s. } \\
\text { 258-263 (art. 39-43) }\end{array}$ \\
\hline IX/X 1444 r. & Płock & Paweł Giżycki & brak \\
\hline XI 1447 r. & Płock & Paweł Giżycki & brak \\
\hline XI 1448 r. & Płock & Paweł Giżycki & brak \\
\hline \multicolumn{4}{|c|}{ Diecezja poznańska } \\
\hline $1413 \mathrm{r}$. & Poznań & Piotr Wysz & NSSP, s. 200-203 \\
\hline VI $1420 \mathrm{r}$. & Poznań & Andrzej Łaskarz & CP, t. 6, s. 143-161 \\
\hline $\mathrm{X} 1421 \mathrm{r}$. & Poznań & Andrzej Łaskarz & brak \\
\hline IX 1424 r. & Poznań & Andrzej Łaskarz & brak \\
\hline $25-27$ I $1430 \mathrm{r}$. & Poznań & Stanisław Ciołek & brak \\
\hline 1430/1431 r. & Poznań & Stanisław Ciołek & brak \\
\hline $1432 \mathrm{r}$. & Poznań & Stanisław Ciołek & brak \\
\hline $1437 \mathrm{r}$. & Poznań & $\begin{array}{l}\text { Stanisław Ciołek } \\
\text { [wikariusz generalny Jakub } \\
\text { Grądzki (?)] } \\
\end{array}$ & brak \\
\hline 5 II $1441 \mathrm{r}$. & Warszawa & Andrzej Bniński & brak \\
\hline 8-9 IV 1442 r. & Poznań & Andrzej Bniński & brak \\
\hline \multicolumn{4}{|c|}{ Diecezja włocławska } \\
\hline $1384 / 1389$ & Włocławek & \begin{tabular}{|l} 
Jan Kropidło \\
\end{tabular} & brak \\
\hline IV $1402 \mathrm{r}$. & Włocławek & Mikołaj Kurowski & SSDW, s. 1-9 \\
\hline 9-11 I $1418 \mathrm{r}$. & Włocławek & $\begin{array}{l}\text { Jan Kropidło } \\
\text { [biskup pomocniczy Wacław } \\
\text { Sporer] }\end{array}$ & brak \\
\hline $15-17 \mathrm{I} 1425 \mathrm{r}$. & Bydgoszcz & Jan Pełła & brak \\
\hline $4 \mathrm{~V} 1427 \mathrm{r}$ & Radziejów & Jan Pełła & SSDW, s. 13-15 \\
\hline \multicolumn{4}{|c|}{ Diecezja wrocławska } \\
\hline $16 \times 1401 \mathrm{r}$. & Wrocław & Wacław Legnicki & brak \\
\hline $16 \times 1406 \mathrm{r}$. & Wrocław & Wacław Legnicki & CP, t. 10 , s. $358-383$ \\
\hline $16 \times 1410 \mathrm{r}$. & Wrocław & Wacław Legnicki & CP, t. 10 , s. $384-396$ \\
\hline 15 X 1418 r. & Wrocław & Konrad Oleśnicki & brak \\
\hline 16 X 1420/1421r. & Wrocław & Konrad Oleśnicki & brak \\
\hline
\end{tabular}




\begin{tabular}{|l|l|l|l|}
\hline \multicolumn{1}{|c|}{ Data synodu } & \multicolumn{1}{|c|}{$\begin{array}{c}\text { Miejsce } \\
\text { Obrad }\end{array}$} & $\begin{array}{l}\text { Biskup [inny duchowny, który } \\
\text { przewodniczył obradom w imieniu } \\
\text { biskupa }\end{array}$ & \multicolumn{1}{|c|}{$\begin{array}{c}\text { Wydane uchwały } \\
\text { (statuty) }\end{array}$} \\
\hline $14-15$ I 1423 r. & Wrocław & $\begin{array}{l}\text { Konrad Oleśnicki } \\
\text { [Konrad ze Zwoli i Teodoryk z } \\
\text { Kluczborka] }\end{array}$ & brak \\
\hline $\begin{array}{l}\text { 26/27-29 V 1446 r. } \\
\text { 1 VII } 1446 \text { r. } 1446 \text { r. }\end{array}$ & Wrocław & $\begin{array}{l}\text { Konrad Oleśnicki (przewodniczy } \\
\text { osobiście) } \\
\text { [opat z Lubiąża Stefan] } \\
\text { [opat z Lubiąża Stefan] }\end{array}$ & CP, t. 10, s. 446-468 \\
\hline $\begin{array}{l}\text { 14 IV(?) 1448 r. } \\
\text { Diecezja wileńska i } \\
\text { żmudzka (brak danych } \\
\text { o synodach w tym } \\
\text { okresie) }\end{array}$ & Wrocław & & CP, t. 10, s. 147-151 \\
\hline
\end{tabular}

ACS - Antiquissimae constitutiones synodales provinciae Gnesnensis; CDB - Codex diplomaticus Brandenburgensis, wyd. A.F. Riedel, cz. 1, t. 20, Berlin 1861; CP - J. Sawicki, Concilia Poloniae, t. 5, 6; NSSP J. Sawicki, Najdawniejsze statuty synodalne poznańskie z rękopisu BOZ 63, „Studia Źródłoznawcze”, 1/1957), s. 191-203; OPP - B. Ulanowski, O pracach przygotowawczych do historii prawa kanonicznego; SDK - B. Ulanowski, Statuty synodalne krakowskie z roku1408, „Archiwum Komisji Historycznej AU”, t. 5, Kraków 1889, s. 21-27; SPPP - Starodawne prawa polskiego pomniki, t. 4: Statuta synodalia episcoporum Cracoviensium XIV et XV saeculi, wyd. U. Heyzmann, Cracoviae 1875; SSAD - W. Wójcik, Statuty synodu archidiecezji gnieźnieńskiej z 1414 r.; SSDW - Statuta synodalia dioecesi Wladislaviensis et Pomeraniae; SSK - S. Zachorowski, Statuty synodalne krakowskie Zbigniewa Oleśnickiego (1436, 1446), Kraków1915; SSWK - Satuty synodalne wieluńsko-kaliskie Mikołaja Trąby z r. 1420, wyd. J. Fijałek, A. Vetulani, Kraków 1915-1920-1951.

Podsumowując przedstawione tu dane, należy stwierdzić, że w latach 1378-1449 w badanych diecezjach i prowincjach kościelnych odbyło się w sumie 71 synodów diecezjalnych, w tym dwa obradujące w dwóch turach i jeden w trzech turach, z czego w metropolii gnieźnieńskiej - 43, w diecezjach pruskich - 15 i w diecezjach frankońskich - 13. Z zaprezentowanych danych wynika ponadto, że w omawianym okresie zwołano 17 synodów prowincjonalnych, z czego w metropolii gnieźnieńskiej - 14 i w metropolii ryskiej - 3 . W całym badanym okresie najwięcej synodów odnotowano w diecezjach: poznańskiej (10), krakowskiej (8) i wrocławskiej (8), natomiast najmniej w diecezjach: chełmińskiej (1) i lubuskiej (1). Dość sporo synodów odnotowano również w diecezji płockiej (7), bamberskiej (6), sambijskiej (6) i włocławskiej (5). Gdy chodzi o zachowane statuty synodalne, to na 71 synodów diecezjalnych tylko dla 35 spośród nich zachowały się wydane na nich statuty. Z kolei trzy wymienione tu synody prowincjonalne metropolii ryskiej znane są właśnie dzięki wydanym na nich zbiorom statutów. W wypadku synodu elbląskiego z 1427 r. zachowało się również kazanie synodalne. Natomiast zupełnie inaczej jest w metropolii gnieźnieńskiej, gdzie tylko dla trzech synodów spośród 14 (21\%) znane są ich uchwały.

Analiza przedstawionych tu danych wymaga dużej ostrożności. Żaden bowiem historyk nigdy nie ma pewności, czy na podstawie zebranych źródeł, często wyrywkowych, ustalił wszystkie synody, które odbyły się w poszczególnych diecezjach. Znana jest niekiedy zapowiedź zwołania synodu, nie ma natomiast innych źródeł, które potwierdzają jego odbycie $^{41}$. Czasami jedynym śladem jego odbycia są wzmianki w księgach konsystorskich,

${ }^{41}$ L. Zygner, Synody diecezjalne, op. cit., s. 168. 
które zawierają zapisy o sprawach rozpoczętych w czasie niedawno odbytych synodów (sądów synodalnych). Stąd o niektórych zgromadzeniach synodalnych wiadomo tylko tyle, że się odbyły, ale jakie i czy w ogóle wydawano na nich uchwały pozostaje wątpliwe. Z kolei w przypadku statutów synodalnych, o ile nie istniała praktyka zapisywania ich do „ksiąg synodalnych" i uzupełniania kolejnymi uchwałami, niewiele z nich miało szansę przetrwać przez wieki. Jak bowiem zauważył Władysław Abraham, wiele z nich - często zapisywanych na pojedynczych kartach - na skutek gromadzenia się nowych uchwał wychodziło z użycia i nie poświęcano im już więcej uwagi, przez co z czasem zupełnie się zatraciły, a tylko część $\mathrm{z}$ nich szczęśliwym trafem zachowała się w dawnych rękopisach ${ }^{42}$. W przypadku niektórych zbiorów statutów, które przetrwały do czasów obecnych nie ma pewności, czy powstały one na jednym, czy na paru synodach (np. zbiór statutów warmińskich z lat 1373-1401). Wszystko to powoduje, że zebrane dane na temat średniowiecznych synodów i ich statutów zawsze będą obarczone pewną dozą wątpliwości, co nie powinno uchodzić uwadze badaczy odwołujących się do tych ustaleń.

\section{Problem częstotliwość zwoływania synodów}

Jednym z najważniejszych zagadnień w badaniach nad synodami dawnych wieków jest ustalenie częstotliwości ich zwoływania. Co prawda kwestie te normowało prawo kościelne ${ }^{43}$, ale w praktyce nie zawsze normy te były zachowywane, a nawet bywały dłuższe okresy zmniejszonej aktywności synodalnej w poszczególnych prowincjach kościelnych ${ }^{44}$. Jak więc wyglądało to w diecezjach frankońskich, pruskich i w metropolii gnieźnieńskiej pod koniec XIV i w pierwszej połowie XV wieku? Aby odpowiedzieć na to pytanie, cały badany tu okres podzieliłem na trzy podokresy: 1378-1399, 1400-1424, 1425-1449, co pozwoli łatwiej uchwycić ewentualne zmiany w natężeniu życia synodalnego w badanych diecezjach. Z przedstawionych danych wynika, że na badanym obszarze w latach 1378-1399 odbyło się 13 lub 11 synodów diecezjalnych (18/15\%), w latach 1400-1424 - 27 lub 25 synodów (38/35\%), a w latach 1425-1449 - 33 synody (46\%). Owe różnice 13 i 11 synodów w latach 1378-1399 oraz 27 i 25 w latach 1400-1424 wynikają z faktu, że nie znane są dokładne daty roczne niektórych synodów warmińskich i sambijskich. W sumie w pierwszej połowie XV wieku synody diecezjalne były zwoływane około 60 razy, co stanowi około 84,5\% synodów całego badanego okresu. W diecezjach frankońskich i w diecezjach pruskich synody zwoływano najczęściej w okresie schizmy bazylejskiej (54\% synodów w diecezjach frankońskich i 33\% synodów w diecezjach pruskich), natomiast w metropolii gnieźnieńskiej najwięcej synodów

\footnotetext{
${ }^{42}$ Najdawniejsze statuty synodalne archidiecezji gnieźnieńskiej oraz statuty z rękopisu OSS. nr 1627, wyd. W. Abraham, Kraków 1920, s. 4-5.

43 Przypomnieć należy, że zgodnie z normami soboru laterańskiego IV z 1215 r. zarówno synody prowincjonalne (concilia provincialia), jak i synody diecezjalne (synodes episcopales) powinny odbywać się każdego roku celem karcenia wykroczeń, reformy obyczajów, zwłaszcza wśród kleru, a także recepcji norm prawa kościelnego (Dokumenty soborów powszechnych. Tekst grecki, łaciński, polski, t. 2: 869-1312, wyd. A. Baron, H. Pietras, Kraków 2003, s. 238-239). Z czasem upowszechniła się praktyka zwoływania synodów prowincjonalnych co najmniej raz na trzy lata, natomiast norma dotycząca corocznych synodów diecezjalnych pozostała ciągle aktualna, co ostatecznie usankcjonowano na soborze bazylejskim w 1433 r., zastrzegając, że jeżeli istnieje zwyczaj zwoływania synodów diecezjalnych dwa razy w roku, to powinien on być zachowany (Dokumenty soborów powszechnych. Tekst grecki, laciński, arabski, ormiański, polski, t. 3: 1414-1445, wyd. A. Baron, H. Pietras, Kraków 2003, s. 320-321, 324-325).

44 J. Helmrath, Partikularsynoden, op. cit., s. 149.
} 
diecezjalnych obradowało w latach dwudziestych i trzydziestych XV wieku (60,5\%), przy czym w okresie trwania schizmy bazylejskiej zwołano ich 15, czyli 35\% wszystkich badanych tu synodów.

Warto dodać, że źródła odnotowały w badanym okresie pewną regularność w zwoływaniu synodów prowincjonalnych w metropolii gnieźnieńskiej, które począwszy od 1398 r., czyli od rządów arcybiskupa Dobrogosta Nowodworskiego, odbywały się średnio co trzy/cztery lata, a w szczytowym okresie obrad soborowych we Florencji i w Rzymie nawet corocznie. Jak można zauważyć, praktyka ta znalazła zwoje odzwierciedlenie w jednym ze statutów wydanych na synodzie prowincjonalnym w Kaliszu w 1406 r., który zobowiązywał arcybiskupa gnieźnieńskiego do zwoływania synodu prowincjonalnego co trzy lata, pod karą 300 grzywien, a biskupów do odbywania corocznych synodów diecezjalnych, z wyjątkiem roku, w którym odbywał się synod prowincjonalny, pod karą 100 grzywien ${ }^{45}$. Statut ten został później powtórzony w kodyfikacji wieluńsko-kaliskiej z 1420 r. ${ }^{46}$ Podobna praktyka znana jest również z ustawodawstwa partykularnego innych metropolii oraz została usankcjonowana dla całego Kościoła łacińskiego w dekrecie soboru bazylejskiego z 1433 r. Poza częstotliwością synodów warto dodać, że na niektórych synodach prowincjonalnych gnieźnieńskich w pierwszej połowie XV wieku obecni byli również biskupi z terenu sąsiedniej metropolii lwowskiej, która wchodziła w skład monarchii Jagiellonów, co jest pewną przesłanką, aby synody te traktować nie tylko jako synody prowincjonalne, ale jako ,synody narodowe” (plenarne), znane dobrze historykom z terenu Rzeszy Niemieckiej. W tym miejscu nie chciałbym jednak tego wątku rozwijać.

Andrzej Radzimiński, opisując aktywność synodalną i ustawodawczą biskupów pruskich omawianego okresu, zauważył, że zwiększenie liczby synodów prowincjonalnych i diecezjalnych w pierwszej połowie XV wieku dobrze wpisuje się w podkreślaną przez Johannesa Helmratha europejską tendencję ożywienia życia synodalnego w okresie działalności wielkich soborów ${ }^{47}$. Niewątpliwie obrady soboru bazylejskiego, a później obrady soboru we Florencji i Rzymie, ożywiły ruch synodalny w diecezjach frankońskich, podobnie jak to miało miejsce w innych diecezjach niemieckich ${ }^{48}$. Również widoczną od lat dwudziestych XV wieku zwiększającą się liczbę synodów diecezjalnych w metropolii gnieźnieńskiej można uznać za przejaw tej samej tendencji ${ }^{49}$. Nie wszyscy jednak historycy z tą tezą się zgadzają. Na przykład Maria Koczerska w recenzji moich prac na temat synodów diecezjalnych metropolii gnieźnieńskiej uznała, że ożywienie synodalne w tej prowincji kościelnej wynikało z dogłębnej dopiero w tym okresie chrystianizacji ludności, umożliwionej rozwojem sieci parafialnej, który był związany z rozwojem osadnictwa w państwie Kazimierza Wielkiego i pierwszych Jagiellonów. Warszawska badaczka wskazała więc bardziej na wewnętrzne

45 Antiquissimae constitutiones, op. cit., s. 221.

46 Statuty synodalne wieluńsko-kaliskie Mikołaja Trąby z r. 1420, wyd. J. Fijałek, A. Vetulani, Kraków 1915-19201951, s. 30-31.

47 A. Radzimiński, Kościół i duchowieństwo, op. cit., s. 262.

48 Zob. np. K. Hübner, Die Provinzialsynoden im Erzbistum Salzburg bis zum Ende des XV. Jahrhunderts, „Deutsche Geschichtsblätter", 10/1909, s. 224 nn.; P. Wiegand, Diözesansynoden und bischöfliche Statutengesetzgebung im Bistum Kammin. Zur Entwicklung des partikularen Kirchenrechts im spätmittelalterlichen Deutschland, Köln 1998, s. $174 \mathrm{nn}$.

49 H. Likowski, Synod prowincjonalny kaliski z r. 1406, „Przegląd Teologiczny”, 6/1925, s. 386-387; L. Zygner, Późnośredniowieczne synody, op. cit., s. 440-441. 
niż zewnętrzne przyczyny ruchu synodalnego w metropolii gnieźnieńskiej na przełomie XIV i XV wieku. Wydaje się jednak, że na ożywienie synodalne w przypadku polskich diecezji mogły oddziaływać zarówno przyczyny wewnętrzne, jak i zewnętrzne, co widać było nie tylko w okresie schizmy bazylejskiej, ale również na synodach prowincjonalnych poprzedzających sobór w Pizie i sobór w Konstancji. Również na synodach diecezjalnych tego okresu dyskutowano o reformie Kościoła. Nieprzypadkowo w dekrecie konwokacyjnym z 13 września 1417 r. biskup włocławski Jan Kropidło wzywał podległych mu duchownych na synod reformationem in capite et in membris fiendam ${ }^{50}$, co ewidentnie nawiązywało do ówczesnych nurtów reformatorskich. Z kolei większa niż wcześniej liczba synodów prowincjonalnych i diecezjalnych w metropolii gnieźnieńskiej w latach trzydziestych i czterdziestych XV wieku - podobnie jak w diecezjach frankońskich i pruskich - miała niewątpliwie związek z recepcją ogłoszonego w 1433 r. na soborze bazylejskim dekretu o synodach prowincjonalnych i diecezjalnych.

Analiza przedstawionych danych nasuwa jednak pytanie: z czego wynikała mniejsza niż w metropolii gnieźnieńskiej częstotliwość zwoływania synodów w diecezjach frankońskich i pruskich w badanym okresie? W tych ostatnich może wynikać to $\mathrm{z}$ braku odpowiednich źródeł (akta biskupie, konsystorskie i kapitulne), na co zwrócili uwagę już wcześniej Andrzej Radzimiński i Arno Mentzel-Reuters ${ }^{51}$. Fragmenty wydanego ostatnio przez Radosława Biskupa Formularza z Uppsali, gdzie znajdują się również wzmianki na temat synodów, wydają się potwierdzać słuszność tej tezy ${ }^{52}$. W przypadku biskupstw frankońskich sprawa wydaje się bardziej złożona. Tu bowiem wyraźne ożywienie synodalne - na przykład w Bambergu i Eichstätt - widać dopiero w okresie reformy bazylejskiej, co przypomina trochę sytuację znaną z innych diecezjach niemieckich ${ }^{53}$. Z drugiej strony we wszystkich diecezjach frankońskich obowiązywały normy synodalne mówiące o obowiązku corocznego zwoływaniu

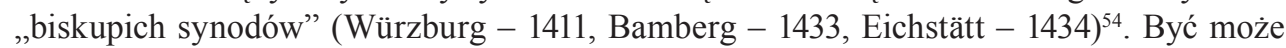
promulgowane już wcześniej zbiory prawa kościelnego tychże diecezji były na tyle wystarczające, że biskupi nie czuli potrzeby częstego zwoływania synodów, a obowiązujące kodyfikacje - trwały efekt zjawiska określanego w nauce zachodniej jako „Drang zur Kodifikation” nowelizowali jedynie w miarę bieżących potrzeb. Przypomnieć trzeba, że w Würzburgu przez kilkadziesiąt lat korzystano ze zbioru statutów biskupa Wolframa z 1329 r. ${ }^{56}$, który później był tylko uzupełniany, stanowiąc podstawę nowelizacji z lat 1407-1411 przeprowadzonej

\footnotetext{
50 Statuta synodalia, op. cit., s. 10.

51 A. Radzimiński, Kościót i duchowieństwo, op. cit., s. 261; A. Mentzel-Reuters, Preußische Diözesanstatuten, op. cit., s. 69-70.

52 „Formularz z Uppsali”. Późnośredniowieczna księga formularzowa biskupstw pruskich, wyd. R. Biskup, Toruń 2016, nr 327, 328, 351, 352, 391, 392.

53 Zob. O.E. Kehrberger, Provinzial- und Synodalstatuten, op. cit., s. 37 nn.; P. Wiegand, Diözesansynoden, op. cit., s. 180-181; H.-J. Schmidt, Kirche, Staat, Nation, op. cit., s. 158. Dobrym przykładem ożywienia synodalnego jest należąca do prowincji magdeburskiej diecezja brandenburska, w której w latach trzydziestych i czterdziestych XV wieku odbyło się co najmniej 10 synodów diecezjalnych: przed 1431, 1434, 1435, 1436, 1437, 1440, 1444, 1446, 1448 (P. Wiegand, Diözesansynoden, op. cit., s. 331).

54 Synodicon, op. cit., s. 233; Die Bamberger Synoden, op. cit., s. 85; J.G. Suttner, Nachträge, op. cit., s. 198.

55 S. Gagnér, Studien zur Ideengeschichte der Gesetzgebung, Stockholm-Uppsala-Göteborg 1960, s. 288 nn.; P. Wiegand, Diözesansynoden, op. cit., s. 57-60.

56 Synodicon, op. cit., s. 163-206.
} 
przez biskupa Johanna von Egloffsteina ${ }^{57}$, a także ogłoszonej w 1446 r. kodyfikacji biskupa Gottfrieda von Limpurga ${ }^{58}$. Podobnie mogło być w diecezji w Eichstätt, gdzie podstawowa kodyfikacja prawa diecezjalnego z 1354 r. ${ }^{59}$ była później tylko uzupełniana, a jej właściwa nowelizacja nastąpiła dopiero na synodzie biskupa Albrechta von Hohenrechberga z $1434 \mathrm{r}$. i na synodzie biskupa Johanna von Eicha z $1447 \mathrm{r} .{ }^{60} \mathrm{Czy}$ jednak obrady synodów to tylko kwestia nowelizacji prawa? Normy dotyczące corocznego zwoływania synodów wynikały przecież także z innych przyczyn. Stąd trudno brakiem potrzeby reformy prawa partykularnego tłumaczyć dość rzadkie synody w diecezji w Bambergu, gdzie z okresu 1402-1433 nie ma żadnej wzmianki o synodzie, a podstawowy zbiór prawa powstał tu dopiero na synodzie biskupa Antona von Rotenhana z 1433 r. ${ }^{61}$, choć tylko w tej diecezji istnieje potwierdzenie odbycia aż czterech synodów na przełomie XIV i XV wieku (1378, 1387, 1394, 1402). Dostrzegając różne możliwości interpretacji tego faktu, przy obecnym stanie wiedzy nie ma wątpliwości, że w badanym okresie ilość synodów w diecezjach pruskich (średnio odbyły się 3-4 synody w diecezji) oraz w diecezjach frankońskich (średnio 4 synody) była mniejsza niż w metropolii gnieźnieńskiej (średnio 6 synodów), choć wszystkie te diecezje pod tym względem znacznie ustępowały diecezjom metropolii praskiej ${ }^{62}$.

Pozostaje jeszcze do omówienia sprawa stosunku poszczególnych biskupów do instytucji synodu diecezjalnego, z uwzględnieniem kryterium częstotliwości zwoływanych przez nich synodów. Co prawda trudno na podstawie ustalonego wykazu synodów wnioskować o gorliwości czy opieszałości biskupów w zwoływaniu synodów, gdyż historyk nie ma nigdy pewności, czy na podstawie zebranych źródeł ustalił wszystkie synody, które rzeczywiście odbyły się w poszczególnych diecezjach ${ }^{63}$. Jednak z innych źródeł wiadomo - powołując się tu na kazanie Mikołaja Ciotczanego ku czci zmarłego biskupa poznańskiego Andrzeja Łaskarza $^{64}$ - że gorliwość w zwoływaniu synodów była w późnym średniowieczu jedną z najbardziej podkreślanych cech biskupiej posługi. Stąd arcybiskupi, często po konsultacjach z innymi biskupami czy wręcz na ich prośbę, a także po zasięgnięciu rady członków kapituły katedralnej, a biskupi ordynariusze po zasięgnięciu rady swoich kapituł katedralnych ${ }^{65}$, starali się w miarę potrzeb zwoływać synody, wydając stosowne dekrety konwokacyjne ${ }^{66}$. Osobiście

\footnotetext{
57 Ibidem, s. 212-233.

58 Ibidem, s. 233-273.

59 J.G. Suttner, Versuch, op. cit., s. 68, 74-76,78-80, 85-88.

60 Ibidem, s. 110-112, 114-116, 118-123; idem, Nachträge, op. cit., s. 193-198. Zob. także O.E. Kehrberger, Provinzial- und Synodalstatuten, op. cit., s. 67-82.

${ }^{61}$ Die Bamberger Synoden, op. cit., s. 48-85.

62 P. Krafl, Wybrane aspekty, op. cit., s. 472; Z. Hledíková, Synoden in der Diözese Prag 1280-1417, w: Partikularsynoden, op. cit., s. 322; L. Zygner, Późnośredniowieczne synody, op. cit., s. 427-428.

63 L. Zygner, Synody diecezjalne, op. cit., s. 168.

64 T. Jurek, Kazanie kanonika Mikołaja Ciotczanego na zgon biskupa poznańskiego Andrzeja Łaskarzyca (1426), „Roczniki Historyczne”, 80/2014, s. 181.

65 S. Zachorowski, Rozwój i ustrój kapituł polskich w wiekach średnich, Kraków 1912, s. 223; S. Hain, Wincenty Kot, op. cit., s. 163; W. Góralski, Kapituła katedralna w Płocku XII-XVI w. Studium z dziejów organizacji prawnej kapituł polskich, Płock 1979, s. 281; L. Zygner, Działalność synodalna arcybiskupa Mikołaja Traby, op. cit., s. 226. M. Czyżak, Kapituła katedralna w Gnieźnie w świetle metryki z lat 1408-1448, Poznań 2003, s. 271.

66 W odniesieniu do synodów prowincjonalnych zob. np.: Modus inquirendi super statu Ecclesiae generalis z pierwszej połowy XV stulecia, wyd. B. Ulanowski, „Archiwum Komisji Historycznej AU”, t. 5, Kraków 1889, s. 214-215 (dekret konwokacyjny wzywający na synod prowincjonalny w Łęczycy wystawiony 25 lipca 1422 r.); Acta capitulorum nec non iudiciorum ecclesiasticorum selecta, wyd. B. Ulanowski, t. 2: Acta iudiciorum ecc-
} 
też - poza nielicznymi wyjątkami, kiedy korzystali z pomocy swoich delegatów ${ }^{67}$ - przewodniczyli obradom synodalnym, a także promulgowali uchwały synodalne przyjęte podczas ich nieobecności ${ }^{68}$. Nieprzypadkowo wielu z nich wkrótce po objęciu diecezji zwoływało synody w celu uporządkowania prawa diecezjalnego. Tak uczynili biskupi: Lamprecht von Brunn w Bambergu (1378), Piotr Wysz w Krakowie (1394) i w Poznaniu (1413), biskup Jakub Kurdwanowski w Płocku (1398), Mikołaj Kurowski we Włocławku (1402), Jan Ryman w Kwidzyniu (1411), Mikołaj Trąba w Uniejowie (1414), Andrzej Łaskarz w Poznaniu (1420), Michał Junge w Królewcu (ok. 1427), Anton von Rotenhan w Bambergu (1433), Gottfried von Limpurg w Würzburgu (1446), Johann von Eich w Eichstätt (1447) czy Piotr Nowak we Wrocławiu (1448). Można więc zaryzykować tezę, że to gorliwość w wypełnianiu biskupich obowiązków, obok konieczności nowelizowania (reformy) kościelnego prawa partykularnego oraz utrzymania karności w diecezji, leżała u podstaw działalności synodalnej biskupów omawianego okresu ${ }^{69}$. Natomiast częstotliwość zwoływania przez nich synodów zależała od osobowości danego biskupa ${ }^{70}$. Bardzo wymowne w tym kontekście są przykłady z sąsiedniej metropolii praskiej, gdzie arcybiskup Jan z Jenštejnu w latach 1379-1396 zwołał aż 20 synodów, a jeden z jego następców Zbynek Zajic z Hazmburka w latach 1402-1411 odprawił

lesiasticorum dioecesum Gneznensis et Poznaniensis (1403-1530), Kraków 1902, nr 189 (dekret konwokacyjny wzywający na synod prowincjonalny w Łęczycy wydany 13 III 1425) - wydawca podał błędną datę dzienną tego dekretu 15 III 1425 (na ten temat: L. Zygner, Działalność synodalna arcybiskupa Wojciecha Jastrzębca, op. cit., s. 66). W odniesieniu do synodów diecezjalnych zob. np.: Liber formularum, ad ius canonicum spectantium, ex actis Jacobi de Kurdwanow episcopi Plocensis maxima parte depromptarum, wyd. B. Ulanowski, „Archiwum Komisji Prawniczej AU”, t. 1, Kraków 1895, nr 22 (dekret konwokacyjny wzywający na synod diecezjalny płocki z 1400 r.); ,Formularz z Uppsali”, op. cit., nr 327, 328, 391, 392 (dekrety konwokacyjne wzywające na synod diecezjalny sambijski z lat 1397/1414); Statuta synodalia, op. cit., s. 9-10 (dekret konwokacyjny wzywający na synod diecezjalny włocławski z 13 września1417 r.); Codex epistolaris saeculi decimi quinti, t. 2, wyd. A. Lewicki, Kraków 1891, nr 140 (dekret konwokacyjny wzywający na synod diecezjalny włocławski z 8 listopada 1424 r.); Constitutiones synodales Warmienses, op. cit., s. 291-292 (dekret konwokacyjny wzywający na synod diecezjalny chełmiński z 12 stycznia 1438 r.); Zbiór dokumentów katedry i diecezji krakowskiej, wyd. S. Kuraś, cz. 2: 1416 -1450, Lublin 1973, nr 438 (dekret konwokacyjny wzywający na synod diecezjalny krakowski z 12 lutego 1443 r.); J. Sawicki, Concilia Poloniae, t. 10: Synody diecezji wrocławskiej i ich statuty, Wrocław 1963, s. $408-409$ (dekret konwokacyjny wzywający na synod diecezjalny wrocławski z 13 kwietnia 1446 r.).

67 Tak było w diecezji krakowskiej w 1408 r., kiedy udający się w podróż zagraniczną biskup Piotr Wysz zlecił odprawienie synodu diecezjalnego wikariuszowi generalnemu Janowi Szafrańcowi, który synod ten odbył w dwóch turach: w dniach 10-11 września 1408 r. w Sandomierzu oraz w dniach 1-2 października w katedrze na Wawelu (L. Zygner, Synody diecezjalne, op. cit., s. 184-185). Z kolei na synodzie diecezjalnym we Włocławku w dniach 9-11 stycznia 1418 r. nieobecnego biskupa Jana Kropidło zastępował jego sufragan, biskup Wacław Sporer (ibidem, s. 220). W diecezji poznańskiej na synodzie w 1437 r. chorego już wówczas biskupa Stanisława Ciołka zastępował jego wikariusz generalny Jakub Grądzki (Z. Kowalska, Stanisław Ciołek, op. cit., s. 77). W diecezji wrocławskiej nieobecnego w stolicy diecezji biskupa Konrada Oleśnickiego na synodzie zebranym w dniach 14-15 stycznia 1423 r. zastępowali ustanowieni przez niego administratorzy diecezji: Konrad ze Zwoli i Teodoryk z Kluczborka, natomiast na synodzie z 1446 r. sesji czwartej (27 czerwca) i sesji piątej (1 lipca) przewodniczył opat cystersów z Lubiąża Stefan (L. Zygner, Wkład Kościoła płockiego, op. cit., s. 105-106).

68 Znany jest taki przykład z prowincji ryskiej, gdzie na skutek oporu ze strony biskupów pruskich, którzy, podlegając władzy wielkiego mistrza zakonu krzyżackiego, nie chcieli uczestniczyć w synodach zwoływanych przez arcybiskupa ryskiego i czynili starania w Stolicy Apostolskiej o zwolnienie ich z tego obowiązku, doszło - zgodnie z wolą papieża Marcina V - do odbycia synodu biskupów pruskich w Elblągu w 1427 r., a przyjęte na nim uchwały zostały później zatwierdzone i promulgowane przez arcybiskupa ryskiego Henniga Scharfenberga. J. Wiśniewski, Średniowieczne synody, op. cit., s. 29-31; A. Radzimiński, Synodalstatuten, op. cit., s. 160.

69 Zob. np. L. Zygner, Drei polnische Bischöfe und Juristen: Peter Wysz, Jakob aus Kurdwanów, Andreas Laskarii und ihre Synodaltätigkeit in den Diözesen Krakau, Plock und Posen, w: Partikularsynoden, op. cit., s. 256-268.

70 P. Krafl, Wybrane aspekty, op. cit., s. 471. 
15 synodów $^{71}$. W konsekwencji wyrażoną przed laty przez Pavla Krafla tezę, że arcybiskupi prascy i biskupi ołomunieccy w swej działalności synodalnej końca XIV i w początkach XV wieku zbliżali się do kanoniczo-prawnego postulatu corocznego zwoływania synodów, rozciągnąłbym także - z pewną ostrożnością - na biskupów metropolii gnieźnieńskiej. Nieco inaczej - tak przynajmniej wynika z zachowanych źródeł - wyglądało to w diecezjach frankońskich i pruskich, choć i tu nie brakowało biskupów gorliwych w zwoływaniu synodów. Natomiast w okresie schizmy bazylejskiej, a zwłaszcza w ostatniej jej fazie, zasada częstego zwoływania synodów była powszechną normą we wszystkich omawianych tu diecezjach.

\section{Bibliografia (do części pierwszej)}

Źródła

Acta capitulorum nec non iudiciorum ecclesiasticorum selecta, wyd. B. Ulanowski, t. 2: Acta iudiciorum ecclesiasticorum dioecesum Gneznensis et Poznaniensis (1403-1530), Kraków 1902.

Antiquissimae constitutiones synodales provinciae Gnesnensis, ed. R. Hube, Petersburg 1856. Codex diplomatcus Brandenburgensis, wyd. A.F. Riedel, cz. 1, t. 20, Berlin 1861.

Codex epistolaris saeculi decimi quinti, t. 2, wyd. A. Lewicki, Kraków 1891.

Constitutiones synodales necnon ordinationes dioecesis Culmensis, Pars I, ed. A. Mańkowski, Torunii 1929.

Constitutiones synodales Warmienses, Sambienses, Pomesanienses, Culmenses necnon provinciales Rigenses, ed. F. Hipler, Brunsberga 1899.

Die Bamberger Synoden, ed. L.C. Schmitt, Bamberg 1851.

Dokumenty soborów powszechnych. Tekst grecki, laciński, arabski, ormiański, polski, t. 3: 1414-1445, wyd. A. Baron, H. Pietras, Kraków 2003.

Dokumenty soborów powszechnych. Tekst grecki, taciński, polski, t. 2: 869-1312, wyd. A. Baron, H. Pietras, Kraków 2003.

„Formularz z Uppsali”. Późnośredniowieczna księga formularzowa biskupstw pruskich, wyd. R. Biskup, Toruń 2016.

Jacobson H.F., Geschichte der Quellen der katholischen Kirchenrechts der Provinzen Preussen und Posen mit Urkunden und Regesten, Königsberg 1837.

Liber formularum, ad ius canonicum spectantium, ex actis Jacobi de Kurdwanow episcopi Plocensis maxima parte depromptarum, wyd. B. Ulanowski, „Archiwum Komisji Prawniczej AU", t. 1, Kraków 1895, s. 1-36.

Modus inquirendi super statu Ecclesiae generalis z pierwszej polowy XV stulecia, wyd. B. Ulanowski, „Archiwum Komisji Historycznej AU”, t. 5, Kraków 1889, s. 197-218.

Najdawniejsze statuty synodalne archidiecezji gnieźnieńskiej oraz statuty z rękopisu OSS. nr 1627, wyd. W. Abraham, Kraków 1920.

Sawicki J., Concilia Poloniae. Źródta i studia krytyczne, t. 4: Najdawniejsze statuty synodalne diecezji chetmskiej z XV w., Lublin 1948.

Sawicki J., Concilia Poloniae. Źródta i studia krytyczne, t. 6: Synody diecezji płockiej i ich statuty, Warszawa 1952.

71 Ibidem, s. 472. 
Sawicki J., Concilia Poloniae. Źródła i studia krytyczne, t. 7: Synody diecezji poznańskiej i ich statuty, Poznań 1952.

Sawicki J., Concilia Poloniae. Źródła i studia krytyczne, t. 10: Synody diecezji wrocławskiej i ich statuty, Wrocław 1963.

Sawicki J., Najdawniejsze statuty synodalne poznańskie z rękopisu BOZ 63, „Studia Źródłoznawcze", 1/1957, s. 191-203.

Starodawne prawa polskiego pomniki, t. 4: Statuta synodalia episcoporum Cracoviensium XIV et XV saeculi, wyd. U. Heyzmann, Cracoviae 1875.

Statuta synodalia dioecesi Wladislaviensis et Pomeraniae, ed. Z. Chodyński, Varsaviae 1890.

Statuty synodalne warmińskie, sambijskie, pomezańskie, chełmińskie oraz prowincjonalne ryskie, tłum. J. Wojtkowski, Olsztyn 2010.

Statuty synodalne wieluńsko-kaliskie Mikołaja Trąby z r. 1420, wyd. J. Fijałek, A. Vetulani, Kraków 1915-1920-1951.

Suttner J.G., Nachträge zur Conciliengeschichte des Bisthums Eichstätt, „Pastoralblatt des Bisthums Eichstätt", 4/1857, s. 193-198.

Suttner J.G., Versuch einer Conciliengeschichte des Bisthums Eichstätt, „Pastoralblatt des Bisthums Eichstätt”, 1/1854, s. 15-16, 19-20, 26-28, 31-32, 36, 38-40, 42-44, 46-48, 50-52, 54-60, 62-64, 66-68, 74-76, 78-80, 85-88, 90-100, 102-104, 108, 110-112,114-116, 118-124, $128,131-32,135-136,138-140,147-148,150-152,158-160,163-164,167-172,174-188,191-$ 192, 194-195, 198-200, 202-204, 206-208, 211-224.

Synodicon Herbipolense. Geschichte und Statuten der im Bisthum Würzburg gehaltenen Concilien und Dioecesansynoden, ed. F.X. Himmelstein, Würzburg 1855.

Ulanowski B., Statuty synodalne krakowskie z roku1408, „Archiwum Komisji Historycznej Akademii Umiejętności”, t. 5, Kraków 1889, s. 21-27.

Wójcik W., Statuty synodu archidiecezji gnieźnieńskiej z 1414 r., „Kościół i Prawo”, t. 5, red. J. Krukowski, Lublin 1988, s. 11-39.

Zbiór dokumentów katedry i diecezji krakowskiej, wyd. S. Kuraś, cz. 2: 1416-1450, Lublin 1973.

Literatura

Binterim A.J., Pragmatische Geschichte des deutschen National-, Provinzial- und vorzüglichsten Diöcesanconcilien vom vierten Jahrhundert bis auf das Concilium zu Trient, t. 1-7, Mainz 1835-1848.

Bylina S., Statuty synodalne jako instrument chrystianizacji wsi w późnym średniowieczu, w: Sacri canones servandi sunt. Ius canonicum et status ecclesiae saeculis XIII-XV, red. P. Krafl, Praha 2008, s. 271-284.

Czyżak M., Kapituła katedralna w Gnieźnie w świetle metryki z lat 1408-1448, Poznań 2003.

Czyżak M., Radzimiński A., Earliest Synod Statutes of John Marienau, Bishop of Chetmno, from the First Half of 15th Century, "Quaestiones Medii Aevii Novae", 24/2019, s. 111-135.

Derwich M., Synoden und Ordensreform im spätmittelalterlichen Polen, w: Partikularsynoden im späten Mittelalter, red. N. Kruppa, L. Zygner, Göttingen 2006, s. 199-214.

Dudziak J., Der gegenwärtige Stand der kirchlichen Rechtsgeschichte in Polen. Ein Grundriß, ,Zeitschrift der Savigny-Stiftung für Rechtsgeschichte. Kanonistische Abteilung”, 81/1995, s. 318-327. 
Erdö P., Synodalbücher der Kirchenprovinzen von Gnesen, Prag und Salzburg. Zu den Erscheinungsformen einer spätmittelalterlichen literarischen Gattung, „Rivista Internazionale di Dritti Comune", 10/1999, s. 9-36.

Fabisz P.W., Wiadomość o synodach prowincyalnych gnieźnieńskich i o prawach kościoła polskiego z dodatkiem spisu synodów dyecezjalnych polskich, Kępno 1861.

Flachenecker H., Das beständige Bemühen um Reform. Zu Synoden und Synodalstatuten in den fränkischen Bistümern des 14./15. Jahrhunderts, w: Partikularsynoden im späten Mittelalter, red. N. Kruppa, L. Zygner, Göttingen 2006, s. 55-75.

Flachenecker H., Rapp F., Lamprecht von Brunn, w: Die Bischöfe des Heiligen Römischen Reiches 1198 bis 1448. Ein biographisches Lexikon, red. E. Gatz, C. Brodkorb, Berlin 2001.

Gagnér S., Studien zur Ideengeschichte der Gesetzgebung, Stockholm-Uppsala-Göteborg 1960.

Góralski W., Kapituła katedralna w Płocku XII-XVIw. Studium z dziejów organizacji prawnej kapituł polskich, Płock 1979.

Góralski W., Stan badań nad średniowiecznym polskim ustawodawstwem synodalnym, „Studia Warmińskie”, 27/1990, s. 13-36.

Góralski W., Wprowadzenie do historii ustawodawstwa synodalnego w Polsce, Lublin 1991.

Gromnicki T., Synody prowincjonalne oraz czynności niektórych funkcjonariuszów apostolskich w Polsce do r. 1457, Kraków 1885.

Grynicz M.M., Aktywność reformatorska arcybiskupa gnieźnieńskiego Jarosława z Bogorii na przykładzie jego działalności ustawodawczej, w: Ecclesia semper reformanda. Kryzysy i reformy średniowiecznego Kościoła, red. T. Gałuszka, T. Graff, G. Ryś, Kraków 2013, s. 273-283.

Günther O., Eine Predigt vom preußischen Provinzialkonzil in Elbing 1427 und die ,Ermahnung des Carthäusers”, „Zeitschrift des Westpreussischen Geschichtsvereins”, 59/1919, s. $69-111$.

Guttenberg von E., Das Bistum Bamberg, t. 1, Berlin 1937.

Hain S., Wincenty Kot prymas Polski 1436-1448, Poznań 1948.

Helmrath J., Partikularsynoden und Synodalstatuten des späteren Mittelalters im europäischen Vergleich. Vorüberlegungen zu einem möglichen Projekt, w: Das europäische Mittelalter im Spannungsbogen des Vergleichs. Zwanzig internationale Beiträge zu Praxis, Problemen und Perspektiven der historischen Komparatistik, red. M. Borgolte, Berlin 2001, s. 135-169.

Hipler F., Die culmischen Diöcesansynode, „Pastoralblatt für die Diöcese Ermland”, 36/1898, s. $63-65$;

Hledíková Z., Synoden in der Diözese Prag 1280-1417, w: Partikularsynoden im späten Mittelalter, red. N. Kruppa, L. Zygner, Göttingen 2006, s. 307-329.

Hübner K., Die Provinzialsynoden im Erzbistum Salzburg bis zum Ende des XV. Jahrhunderts, „Deutsche Geschichtsblätter”, 10/1909, s. 187-236.

Jakubowski Z., Ustawodawstwo synodalne arcybiskupów gnieźnieńskich z lat 1420-1423 jako wyraz stosunku polskiej hierarchii kościelnej do husytyzmu. Wstępna charakterystyka zjawiska i perspektywy badań, „Studie o rukopisech”, 29/1992, s. 69-78.

Johannek P., Zur kirchlischen Reformtätigkeit Bischof Lamprechts von Brunn, „Bericht des Historischen Vereins für die Pflege des Geschichte des ehemaligen Fürstbistums Bamberg”, 102/1966, s. 235-256. 
Jurek T., Kazanie kanonika Mikołaja Ciotczanego na zgon biskupa poznańskiego Andrzeja Laskarzyca (1426), „Roczniki Historyczne”, 80/2014, s. 169-184.

Karbownik H., Wiadomość o synodzie diecezji krakowskiej z 1443 roku, „Roczniki Teologiczno-Kanoniczne", 30/1983, z. 5, s. 158-159.

Kehrberger E.O., Provinzial- und Synodalstatuten des Spätmittelalters. Eine quellenkritische Untersuchung der Mainzer Provinzialgesetze des 14. und 15. Jahrhunderts und der Synodalstatuten der Diözesen Bamberg, Eichstätt und Konstanz, Stuttgart 1938.

Kłapkowski W., Działalność kościelna biskupa Wojciecha Jastrzębca, Warszawa 1932.

Knapek E., Piotr Wysz wobec kryzysu Kościoła, w: Ecclesia semper reformanda. Kryzysy i reformy średniowiecznego Kościoła, red. T. Gałuszka, T. Graff, G. Ryś, Kraków 2013, s. 301-310.

Koczerska M., Oleśnicki Zbigniew, w: Polski Słownik Biograficzny, t. 23, Wrocław 1978, s. 776-784.

Koczerska M., Zbigniew Oleśnicki i Kościół krakowski w czasach jego pontyfikatu (1423-1455), Warszawa 2004.

Konarska-Zimnicka S., ,Nie szata zdobi człowieka”. Polskie statuty synodalne w walce o skromność ubioru duchownych, w: Ecclesia semper reformanda. Kryzysy i reformy średniowiecznego Kościoła, red. T. Gałuszka, T. Graff, G. Ryś, Kraków 2013, s. 443-464.

Kowalska Z., Stanisław Ciołek († 1437), podkanclerzy królewski, biskup poznański, poeta dworski, Kraków 1993.

Krafl P., Polské provinciální synody 13.-15. století, Praha 2016.

Krafl P., Přehled provinciálních synod Hnězdna z let 1206-1503, „Slovanské historické studie", 25/1999, s. 5-34.

Krafl P., Provinciální synody hnězdenské církevní provincie do začátku 16. století, „Prawo Kanoniczne", 43/2000, nr 1-2, s. 37-78.

Krafl P., Synody a synodální zákonodártví ve středovýchodni Evropě. Přehled bádání za poslednich patnáct let, „Český Časopis Historický”, 111/2013, nr 1, s. 117-143.

Krafl P., Wybrane aspekty życia synodalnego w diecezjach praskiej, ołomunieckiej, wrocławskiej i litomyskiej do końca XV wieku. Porównanie, „Śląski Kwartalnik Historyczny Sobótka", 54/1999, s. 467-482.

Krawiec A., Problematyka malżeńska $w$ średniowiecznym ustawodawstwie synodalnym Kościoła polskiego, w: Docendo discimus. Studia historyczne ofiarowane profesorowi Zbigniewowi Wielgoszowi w siedemdziesiata rocznice urodzin, red. K. Kaczmarek, J. Nikodem, Poznań 2000, s 247-284.

Krollmann C., Eine merkwürdige samländische Urkunde, „Altpreußische Forschungen”, 11/1934, s. 32-38.

Kumor B.S., Dzieje diecezji krakowskiej do roku 1795, t. 2, Kraków 1999.

Lang P.T., Die Synoden in der alten Diözese Würzburg, „Rottenburger Jahrbuch für Kirchengeschichte", 5/1986, s. 71-84.

Likowski H., Synod prowincjonalny kaliski z r. 1406, „Przegląd Teologiczny”, 6/1925, s. $377-390$.

Mentzel-Reuters A., Preussische Diözesanstatuten und Reformen im Deutschen Orden, w: Von der Ordnung zur Norm. Statuten in Mittelalter und Früher Neuzeit, red. G. Drossnach, Paderborn 2010, s. 55-70.

Morawski M., Synod diecezjalny w dawnej Polsce, Włocławek 1937. 
Morawski M., Synod prowincjonalny prowincji gnieźnieńskiej w dawnej Polsce, Włocławek 1935.

Mrozowicz W., Breslauer Synoden des Mittelalters und ihre Widerspiegelung in den Quellen. Ausgewähle Probleme, w: Partikularsynoden im späten Mittelalter, red. N. Kruppa, L. Zygner, Göttingen 2006, s. 275-287.

Nowacki J., Synody diecezji poznańskiej w latach 1252-1738, Poznań 2004.

Ożóg K., Biskupa Wojciecha Jastrzębca „,paterna sollicitudo” o Kościót krakowski. Statuty synodalne z roku 1420, w: Wojciech Jastrzębiec - w stużbie monarchii i Kościoła, red. B. Czwojdrak, F. Kiryk, J. Sperka, Katowice 2018, s. 145-160.

Ożóg K., Kleine Pastoralkompendien in den spätmittelalterlichen Synodalstatuten Polens, w: Partikularsynoden im späten Mittelalter, red. N. Kruppa, L. Zygner, Göttingen 2006, s. 215-237.

Ożóg K., Małżeństwo w polskim ustawodawstwie synodalnym wieków średnich, w: Manželstvi v pozdním středověku. Rituály a obyčeje, red. P. Krafl, M. Nodl, Praha 2014, s. 15-33.

Ożóg K., , Pastor bonus” - duszpasterskie zabiegi biskupa Zbigniewa Oleśnickiego w diecezji krakowskiej, w: Zbigniew Oleśnicki książę Kościoła i mą̇̇ stanu, red. F. Kiryk, Z. Noga, Kraków 2006, s. 159-161.

Partikularsynoden im späten Mittelalter, red. N. Kruppa, L. Zygner, Göttingen 2006.

Pontal O., Le rôle du synode diocésain et des statuts synodaux dans la formation du clergé, w: Les évèques, les clercs et le roi (1250-1300), Toulouse 1972, s. 337-359.

Radzimiński A., Kościót i duchowieństwo w średniowieczu. Polska i państwo zakonu krzyżackiego w Prusach, Toruń 2012.

Radzimiński A., Prawo kościelne oraz procesy ewangelizacyjne w państwie zakonu krzyżackiego w Prusach, w: Sacri canones servandi sunt. Ius canonicum et status ecclesiae saeculis XIII-XV, red. P. Krafl, Praha 2008, s. 258-270.

Radzimiński A., Synodalstatuten im Deutschordensland Preußen, w: Partikularsynoden im späten Mittelalter, red. N. Kruppa, L. Zygner, Göttingen 2006, s. 157-176.

Radzimiński A., Udział zakonu krzyżackiego w procesie ewangelizacji Prus. Uwagi na podstawie ustawodawstwa synodalnego, ,Zapiski Historyczne”, 60/2005, z. 1, s. 7-26.

Radzimiński A., Ustawodawstwo synodów diecezjalnych w państwie zakonu krzyżackiego w Prusach. Uwagi do problemu, w: Ecclesia-cultura-potestas. Studia z dziejów kultury i społeczeństwa, red. P. Kras, A. Januszek, A. Nalewajek, W. Polak, Kraków 2006, s. $145-155$.

Sawicki J., Geschichte und heutiger Stand der Vorarbeiten zur Gesamtausgabe der polnischen Synodalstatuten, ,Zeitschrift der Savigny-Stiftung für Rechtsgeschichte. Kanonistische Abteilung", 46/1960, s. 395-429.

Schmidt H.-J., Kirche, Staat, Nation. Raumgliederung der Kirche im mittelalterlichen Europa, Weimar 1999.

Skierska I., Obowiązek mszalny w średniowiecznej Polsce, Warszawa 2003.

Skierska I., Sabbatha sanctifices. Dzień święty w średniowiecznej Polsce, Warszawa 2008.

Studt B., Papst Martin V. (1417-1431) und die Kirchenreform in Deutschland, Köln-Weimar-Wien 2004.

Subera I., Synody prowincjonalne arcybiskupów gnieźnieńskich. Wybór tekstów ze zbioru Jana Wężyka z r. 1761, wyd. 2, Warszawa 1981.

Szymborski W., Odpusty w średniowiecznej Polsce, Kraków 2011. 
Tymosz S., Ewolucja kościelnego prawa polskiego w świetle kodyfikacji do XIX wieku, Lublin 2008.

Tymosz S., Gnesener Provinzial- und Diözesansynoden im 14. und 15. Jahrhundert - Ein Überblick, w: Partikularsynoden im späten Mittelalter, red. N. Kruppa, L. Zygner, Göttingen 2006, s. 177-198.

Uruszczak W., Ustawodawstwo synodów Kościoła katolickiego w Polsce w XIII i XIV wieku, „Czasopismo Prawno-Historyczne”, 51/1999, z. 1-2, s. 133-148.

Uruszczak W., Z takim sposobem uprawiania nauki zgodzić się nie można! Twórczość historyczno-prawna ks. dra hab. Stanisława Tymosza z lat 2003-2008, „Studia z Dziejów Państwa i Prawa Polskiego", 13/2010, s. 265-284.

Wendehorst A., Das Bistum Eichstätt, t. 1: Die Bischofsreihe bis 1535, Berlin 2006.

Wendehorst A., Das Bistum Würzburg, cz. 2: Die Bischofsreihe von 1254 bis 1455, Berlin 1969. Wiegand P., Diözesansynoden und bischöfliche Statutengesetzgebung im Bistum Kammin. Zur Entwicklung des partikularen Kirchenrechts im spätmittelalterlichen Deutschland, Köln 1998.

Wiśniewski J., Średniowieczne synody pomezańskie. Dekanat sztumski (1601-1821), Elbląg 1999.

Wojciechowska B., Duchowni włóczędzy w świetle ustawodawstwa synodalnego metropolii gnieźnieńskiej, w: Samotrzeć, w kompanii czy z orszakiem. Społeczne aspekty podróżowania $w$ średniowieczu $i$ w czasach nowożytnych, red. M. Saczyńska, E. Wółkiewicz, Warszawa 2012, s. 53-67.

Wojciechowska B., Małzeństwo w ustawodawstwie synodalnym Kościoła polskiego w późnym średniowieczu, „Czasopismo Prawno-Historyczne”, 67/2015, z. 1, s. 21-29.

Wójcik W., Ze studiów nad synodami polskimi, Lublin 1982.

Wünsch T., Das Reformprogramm des Krakauer Bischofs Petrus Wysz 1391-1412. Mit Neueedition der 22-Punkte-Liste „De reformatione ecclesie”, w: Kirchliche Reformimpulse des 14./15. Jahrhunderts in Ostmitteleuropa, red. W. Eberhard, F. Machilek, Köln-Weimar-Wien 2006, s. 157-178.

Wünsch T., Partikularsynoden als Normierungsinstanzen am Vorabend der Reformation (Beispiele aus Böhmen-Mähren, Schlesien und Polen), w: Partikularsynoden im späten Mittelalter, red. N. Kruppa, L. Zygner, Göttingen 2006, s. 289-306.

Wünsch T., Ritual und Politik. Partikularsynoden als Instrumente der politischen Willensbildung in der polnisch-litauischen Adelsrepublik, w: Ritualisierung politischer Willensbildung. Polen und Deutschland im hohen und späten Mittelalter, red. W. Fałkowski, B. Schneidmüller, S. Weinfurter, Wiesbaden 2010, s. 243-258.

Wünsch T., Typologie und Funktionalität der polnischen Synoden. Neue Fragenstellungen, „Annuarium Historiae Conciliorum”, 40/2008, s. 561-570.

Zachorowski S., Rozwój i ustrój kapituł polskich w wiekach średnich, Kraków 1912.

Zachorowski S., Studia z historii prawa kościelnego i polskiego, Kraków 1917.

Zawadzki W., Model kapłana pomezańskiego wXVw. w świetle ustawodawstwa synodalnego, w: Studia z dziejów diecezji pomezańskiej w 775. rocznice jej utworzenia, red. J. Liguz, Pelplin 2020, s. 137-148.

Zygner L., „Concilia Poloniae” - niedokończona seria wydawnicza, w: Editiones sine fine, t. 1, red. K. Kopiński, W. Mrozowicz, J. Tandecki, Toruń 2017, s. 189-201. 
Zygner L., Die Kinder in den mittelalterlichen Synodalstatuten Polens. Eine Skizze, „Documenta Pragensia", 31/2012, s. 103-118.

Zygner L., Drei polnische Bischöfe und Juristen: Peter Wysz, Jakob aus Kurdwanów, Andreas Laskarii und ihre Synodaltätigkeit in den Diözesen Krakau, Ptock und Posen, w: Partikularsynoden im späten Mittelalter, red. N. Kruppa, L. Zygner, Göttingen 2006, s. 256-268.

Zygner L., Działalność synodalna arcybiskupa Mikołaja Kurowskiego, „Roczniki Historyczne", 78/2012, s. 107-125.

Zygner L., Działalność synodalna arcybiskupa Mikołaja Traby, w: Piśmienność pragmatyczna-edytorstwo źródet historycznych - archiwistyka. Studia ofiarowane Profesorowi Januszowi Tandeckiemu w sześćdziesiąta piąta rocznicę urodzin, red. R. Czaja, K. Kopiński, Torun 2015, s. 213-231.

Zygner L., Działalność synodalna arcybiskupa Wojciecha Jastrzębca (próba retrospekcji i reinterpretacji), „Studia Mazowieckie”, 10(24)/2015, nr 3, s. 59-82.

Zygner L., Instytucja synodu diecezjalnego w życiu Kościoła płockiego (XIII-XVIII wiek), w: Mazowsze w retrospektywie badawczej. Dynastie, instytucje, społeczeństwo, red. W. Graczyk, J.M. Marszalska, B. Dźwigała, Kraków 2016, s. 123-152.

Zygner L., Kilka uwag w sprawie synodów diecezji lubuskiej w średniowieczu, w: Memoria viva. Studia historyczne poświęcone pamięci Izabeli Skierskiej (1967-2014), Warszawa-Poznań 2015, s. 415-423.

Zygner L., Kodyfikacja płocka biskupa Jakuba Kurdwanowskiego z przełomu XIV i XV wieku, w: $W$ mazowieckiej przestrzeni kulturowej. Prace ofiarowane $w$ 80. rocznice urodzin Profesora Ryszarda Juszkiewicza, red. B. Dymek, Warszawa 2007, s. 33-79.

Zygner L., Nieznany synod prowincjonalny arcybiskupa Dobrogosta Nowodworskiego z 1398 roku, „Studia Mazowieckie”, 7(14)/2012, nr 3, s. 83-93.

Zygner L., Późnośredniowieczne synody narzędziem reformy Kościoła, w: Ecclesia semper reformanda. Kryzysy i reformy średniowiecznego Kościoła, red. T. Gałuszka, T. Graff, G. Ryś, Kraków 2013, s. 423-441.

Zygner L., Reforma prawa partykularnego metropolii gnieźnieńskiej w XV i na poczatku XVI wieku oraz jej wplyw na ustawodawstwo diecezji wileńskiej i żmudzkiej, w: Kultūra - ekonomika - visuomené: squeika ir pokyčiai viduramžiais ir ankstyvaisiais naujaisiais laikais Baltijos rytineje pakrantèje, red. M. Ščavinkas, Klaipèda 2015, s. 112-134.

Zygner L., Synody diecezjalne metropolii gnieźnieńskiej na przełomie XIV i XV wieku (Gniezno-Kraków-Płock-Poznań-Włoctawek), w: Kultura prawna w Europie Środkowej, red. A. Barciak, Katowice 2006, s. 165-226.

Zygner L., W sprawie synodów arcybiskupa gnieźnieńskiego Janusza Suchegowilka (13741382), w: Kościót i duchowieństwo w średniowiecznej Polsce i na obszarach sasiednich, red. R. Biskup, A. Radzimiński, Toruń 2013, s. 223-242.

Zygner L., W sprawie synodu prowincjonalnego w Uniejowie w 1414 r., w: Si vis pacem, para bellum. Bezpieczeństwo i polityka Polski. Księga jubileuszowa ofiarowana profesorowi Tadeuszowi Dubickiemu, red. R. Majzer, Częstochowa-Włocławek 2013, s. 1136-1144.

Zygner L., Wkład Kościoła płockiego i wrocławskiego w życie synodalne metropolii gnieźnieńskiej końca XIV i pierwszej połowy XV wieku, „Studia Mazowieckie”, 10(24)/2015, nr 3, s. 83-117. 